\title{
A study on the relationship between mass concentrations, chemistry and number size distribution of urban fine aerosols in Milan, Barcelona and London
}

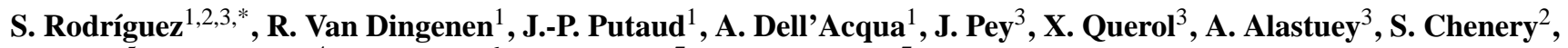 \\ K.-F. Ho ${ }^{5}$, R. Harrison ${ }^{4}$, R. Tardivo ${ }^{6}$, B. Scarnato ${ }^{7}$, and V. Gemelli ${ }^{7}$ \\ ${ }^{1}$ European Commission - DG Joint Research Centre, Institute for Environment and Sustainability, T.P. 290, Ispra (VA) 21020, \\ Italy \\ ${ }^{2}$ British Geological Survey, Keyworth, Nottingham, NG12 5GG, UK \\ ${ }^{3}$ Institute of Earth Science "Jaume Almera", CSIC, Solé i Sabarís, S/N, 08028, Barcelona, Spain \\ ${ }^{4}$ University of Birmingham, Division of Environmental Health and Risk Management, Edgbaston, Birmingham B15 2TT, UK \\ ${ }^{5}$ Hong Kong Polytechnic University, Department of Civil and Structural Engineering, TU418, Hung Hom, Kowloon, Hong \\ Kong \\ ${ }^{6}$ Politecnico di Milano, Piazza Leonardo da Vinci, 32-20133 Milan, Italy \\ ${ }^{7}$ ARPA-Lombardia, Viale Francesco Restelli, 3/1, 20124 Milan, Italy \\ * currently at: University of Huelva (Spain) at the Izaña Atmospheric Observatory, INM-CSIC, La Marina 20, 6a planta, \\ 38071, Santa Cruz de Tenerife, Canary Islands, Spain
}

Received: 3 November 2006 - Published in Atmos. Chem. Phys. Discuss.: 16 January 2007

Revised: 16 April 2007 - Accepted: 16 April 2007 - Published: 3 May 2007

\begin{abstract}
A physicochemical characterization, including aerosol number size distribution, chemical composition and mass concentrations, of the urban fine aerosol captured in MILAN, BARCELONA and LONDON is presented in this article. The objective is to obtain a comprehensive picture of the microphysical processes involved in aerosol dynamics during the: 1) regular evolution of the urban aerosol (daily, weekly and seasonal basis) and in the day-to-day variations (from clean-air to pollution-events), and 2) the link between "aerosol chemistry and mass concentrations" with the "number size distribution".

The mass concentrations of the fine $\mathrm{PM}_{2.5}$ aerosol exhibit a high correlation with the number concentration of $>100 \mathrm{~nm}$ particles $\mathrm{N}>100(\mathrm{~nm})$ ("accumulation mode particles") which only account for $<20 \%$ of the total number concentration $\mathrm{N}$ of fine aerosols; but do not correlate with the number of $<100 \mathrm{~nm}$ particles ("ultrafine particles"), which accounts for $>80 \%$ of fine particles number concentration. Organic matter and black-carbon are the only aerosol components showing a significant correlation with the ultrafine particles, attributed to vehicles exhausts emissions; whereas ammonium-nitrate, ammonium-sulphate and also organic matter and black-carbon correlate with $\mathrm{N}>100$ $(\mathrm{nm})$ and attributed to condensation mechanisms, other par-
\end{abstract}

Correspondence to: S. Rodríguez

(srodriguez@inm.es) ticle growth processes and some primary emissions. Time series of the aerosol DpN diameter (dN/dlogD mode), mass $\mathrm{PM}_{2.5}$ concentrations and number $\mathrm{N}>100(\mathrm{~nm})$ concentrations exhibit correlated day-to-day variations, which point to a significant involvement of condensation of semi-volatile compounds during urban pollution events. This agrees with the observation that ammonium-nitrate is the component exhibiting the highest increases from mid-to-high pollution episodes, when the highest DpN increases are observed. The results indicates that "fine $\mathrm{PM}_{2.5}$ particles urban pollution events" tend to occur when condensation processes have made particles grow large enough to produce significant number concentrations of $\mathrm{N}>100$ (nm) ("accumulation mode particles"). In contrast, because the low contribution of ultrafine particles to the fine aerosol mass concentrations, high "ultrafine particles $\mathrm{N}<100(\mathrm{~nm})$ events" frequently occurs under low $\mathrm{PM}_{2.5}$ conditions. The results of this study demonstrate that vehicles exhausts emissions are strongly involved in this ultrafine particles aerosol pollution.

\section{Introduction}

Atmospheric aerosol (or particulate matter-PM) is now one of the air pollutants of most concern owing to its ability to influence climate, its adverse effects on human health and

Published by Copernicus GmbH on behalf of the European Geosciences Union. 
the difficulties in controlling their emissions (e.g. Wichmann et al., 2000; Sun et al., 2005; IPCC, 2001). Studies on urban fine atmospheric aerosol are a growing interest as: 1) the aerosol characterisation is difficult because it is made up of a complex mixture of solid and liquid substances (some of them semi-volatile) with a large range in particle size and 2) the still poorly characterised links between "urban and regional air quality" and "climate change".

This concern on the aerosol pollution effects has prompted several studies focused on the physical and chemical characterisation of aerosols throughout Europe (e.g. Ruuskanen et al., 2001; Wehner and Wiedensohler, 2003; Laakso et al., 2003; Hussein et al., 2004; Kulmala et al., 2004; Van Dingenen et al., 2004; Putaud et al., 2004; Querol et al., 2004; Götschi et al., 2005; Rodríguez et al., 2006). The studies centred on the urban aerosol physical properties have provided very valuable information on the aerosol sources and evolution in terms of "number size distribution" (e.g. Wehner and Wiedensohler, 2003; Hussein et al., 2004). Moreover, the studies focused on the aerosol chemical characterisation, mass-closure and source apportionment, have shown that, in Europe, fine $\mathrm{PM}_{2.5}$ particles are mainly constituted (in terms of mass concentrations) by primary (organic matter and black-carbon) and secondary (organic matter, sulphate, nitrate and ammonium) matter linked to combustion emissions, and also by mineral dust and sea salt (e.g. Putaud et al., 2004; Querol et al., 2004; Götschi et al., 2005; Rodríguez et al., 2006). Although the number of such studies on the aerosol chemistry and physic is significant, these parameters and factors have been mostly studied separately, i.e. in unconnected contexts. Because of this, although the sources and composition of fine particles are being better understood (except the biogenic contribution to organic matter; e.g. Janson et al., 2001), there are still significant uncertainties. The involvement of the different microphysical processes that influence aerosol dynamics (i.e. nucleation, coagulation, condensation, evaporation, etc...), in "urban and regional fine aerosol pollution events", has not been deeply characterized. In order to contribute to reducing the uncertainties, a study on fine aerosols chemical composition, mass concentrations and number size distribution in three cities of Western Europe MILAN, BARCELONA \& LONDON has been conducted. The objectives are: 1) to provide a comprehensive picture on the involvement of the above cited microphysical processes in the regular daily, weekly and seasonal evolution of the urban aerosol, and 2) to study the microphysical processes leading to high mass concentration episodes by linking the aerosol chemistry with the changes in the number size distribution. For this purpose, the data set from each study city was analysed in detail. Despite the size of the database and because data reduction methods have been avoided to minimise information loss, the set of analysis performed provided a large volume of results. The current report aims to synthesize the key findings, in order to provide a general overview of fine urban aerosols. Finally, the implications of the study findings for the authors" "view" of urban aerosol pollution are discussed.

\section{Study regions}

The factors affecting the transport and dispersion of pollutants in Western Europe, as well as the aerosol composition, varies significantly from south to north (Millán et al., 2002; Rodríguez et al., 2006). The three cities selected for this study are representative of some of these differences (Fig. 1).

LONDON is located within a meteorological context favouring the frequent renovation of air masses. This is due to the relatively flat terrain, the predominant mean westerly winds and frequent passages of cold fronts and depressions resulting in rain (Fig. 1). These are the predominant conditions north of the Alps and Pyrenees. In contrast, the areas surrounding the Western Mediterranean basin are characterised by an abrupt topography, which coupled with the characteristic synoptic scale patterns, results in low mean wind speeds and regional circulations that hinder the air mass renovations and favour the accumulation of aerosols in the surroundings of emission regions (Fig. 1).

BARCELONA is within a region where meteorological conditions support the occurrence of high background levels of PM due to: 1) the predominant meteorology of weak gradient conditions and regional recirculations favouring regional pollution events; 2) the low precipitation rates in the region (the lowest of Europe) increasing the residence time of aerosols; 3) an enhancement of the mineral dust resuspension processes in cities (by road traffic) due to scarce road cleaning and low precipitation rates, and in rural areas due to the arid soils.

MILAN is within the bottom of the Po valley, where intense urban pollution events are favoured by the very low wind speed and the frequent occurrence of inversion layers near the ground in winter.

These differentiated conditions in the three cities are clearly evidenced in the local meteorological variables, such as in-situ wind speed (Fig. 1f) and the boundary layer depth (BLD; Fig. 1e). For example, observe how in summer the BLD maximises in Milan and London because of the thermal convective activity; whereas in Barcelona it exhibits a minimum owing to the subsidence over the coast, in turn, because of the vertical recirculation of air masses along the coastal ranges (resulting in a decrease in the "thickness of the in-land sea breeze layer").

Saharan dust transport is another factor that differentiates the Mediterranean aerosol composition, as this occurs with a much higher frequency in southern than in central-northern Europe. 

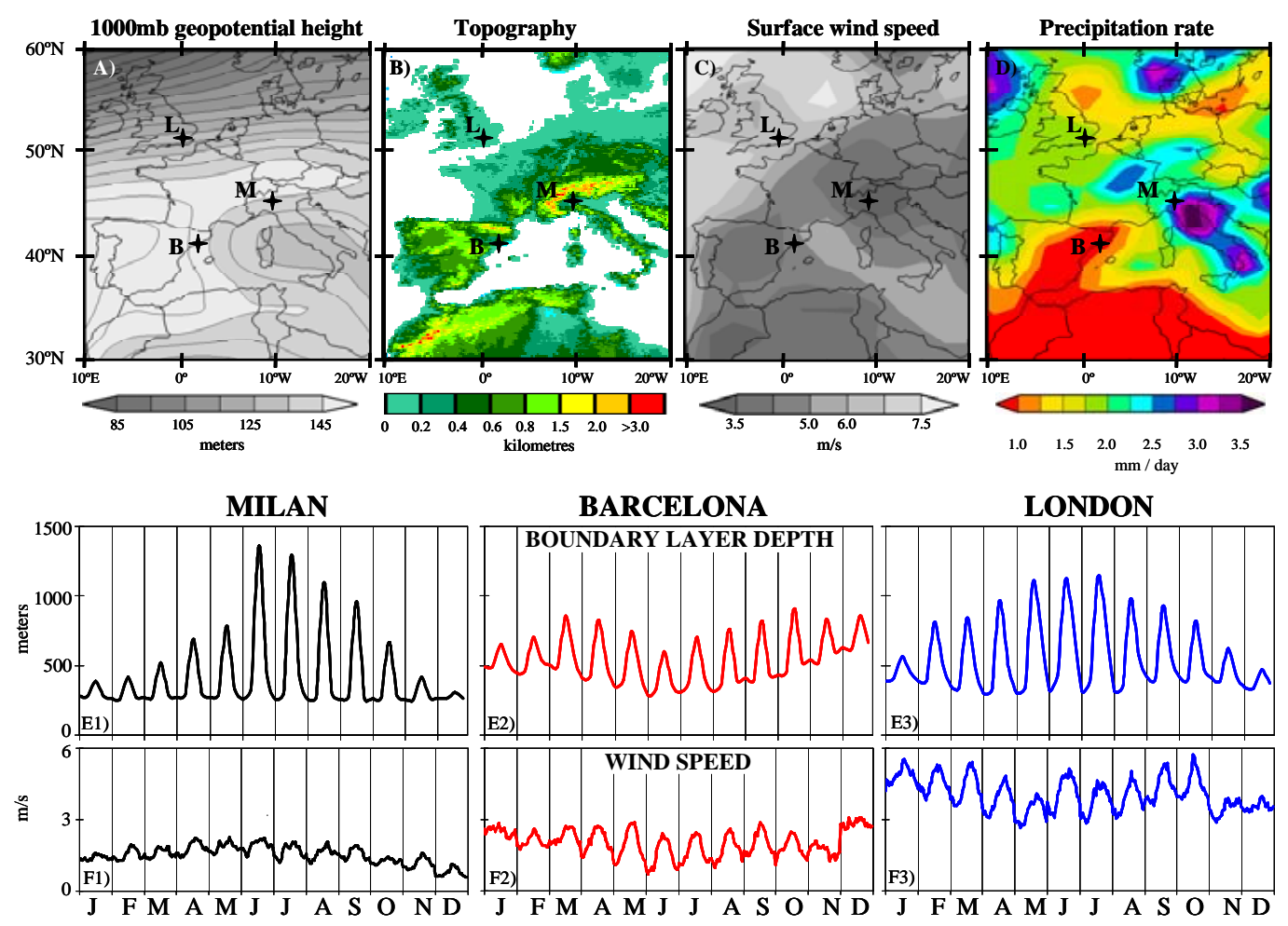

Fig. 1. Maps of topography and 2000-2005 climatology of several meteorological fields over Europe (A-D) and daily mean evolution per month during 2004 of the Boundary Layer Depth and in-situ wind speed (E-F) at London (L), Barcelona (B) and Milan (M).

\section{Methodology}

This study was performed in "central urban background sites" of MILAN (Via-Messina; $45^{\circ} 29^{\prime} 03.29^{\prime \prime} \mathrm{N}$, $9^{\circ} 10^{\prime} 21.63^{\prime \prime} \mathrm{E}, 130.75 \mathrm{~m}$ above the sea level, $\mathrm{m}$ a.s.l.), BARCELONA (Institute "Jaume Almera" - CSIC; $41^{\circ} 23^{\prime} 5^{\prime \prime} \mathrm{N}, 2^{\circ} 7^{\prime} 9^{\prime \prime} \mathrm{E}, 63.40 \mathrm{~m}$ a.s.l.) and LONDON (Bloomsbury; $51^{\circ} 31^{\prime} 20.50^{\prime \prime} \mathrm{N}, 0^{\circ} 7^{\prime} 32.84^{\prime \prime} \mathrm{E}, 32.91 \mathrm{~m}$ a.s.1.). The measurement site in: 1) MILAN is located into a large area where the access is restricted (in the fire brigade station); 2) BARCELONA is located over the roof of a 2 floors building in the university campus, and 3) LONDON is located in a small park in Russell Square.

\subsection{Aerosol chemical characterization}

Sampling of $\mathrm{PM}_{2.5}$ (24-h sampling) was performed on quartz filters once every 4 days using DIGITEL ${ }^{\mathrm{TM}}$ high volume samplers. After filter conditioning, mass concentrations were determined by gravimetry. The concentrations of non-seasalt- $\mathrm{SO}_{4}^{=}, \mathrm{NO}_{3}^{-}, \mathrm{NH}_{4}^{+}$, sea salt $\left(\mathrm{Na}+\mathrm{Cl}+\right.$ sea-salt- $\left.\mathrm{SO}_{4}^{=}\right)$, mineral dust $\left(\mathrm{Al}_{2} \mathrm{O}_{3}+\mathrm{SiO}_{2}+\mathrm{Ca}+\mathrm{CO}_{3}^{=}+\mathrm{Ti}+\mathrm{Fe}+\mathrm{Sr}\right)$, organic matter $\left(\mathrm{OM}=1.6^{*} \mathrm{OC}\right)$, black carbon $(\mathrm{BC})$ and some trace elements, were determined by ion chromatography, thermaloptical-reflectance, ICP-AES, ICP-MS and some indirect determinations as described by Querol et al.(2001) and Cao et al. (2004). A total of 96,94 and $65 \mathrm{PM}_{2.5}$ samples from MILAN, BARCELONA \& LONDON were analysed in this 1-year study, respectively.

\subsection{Aerosol physical characterization}

Aerosol number size distribution measurements were performed by using a Differential Mobility Analyzer (model 3071 of TSI $^{\mathrm{TM}}$ ) connected to Condensation Particles Counter (model 3022 of TSI ${ }^{\mathrm{TM}}$ ). The particles size distribution measurements were performed in the Differential Mobility Particle Sizer mode between 10 and $800 \mathrm{~nm}$ by using custom software at MILAN and BARCELONA, whereas at LONDON these were performed in the Scanning Mobility Particle Sizer mode between 10 and $415 \mathrm{~nm}$ by using the $\mathrm{TSI}^{\mathrm{TM}}$ software.

Gravimetric equivalent hourly mass concentrations of $\mathrm{PM}_{2.5}$ were determined by multiplying the hourly concentrations of the aerosol volume (in MILAN), OPC-GRIMM ${ }^{\mathrm{TM}}$ $\mathrm{PM}_{2.5}$ (in BARCELONA) and TEOM ${ }^{\mathrm{TM}} \mathrm{PM}_{2.5}$ (in LONDON) by factors (slope of the linear relationships) obtained by cross correlating the aerosol volume (MILAN), the "GRIMM ${ }^{\mathrm{TM}}$ " $\mathrm{PM}_{2.5}$ (in BARCELONA) and the "TEOM" ${ }^{\mathrm{TM}}$, $\mathrm{PM}_{2.5}$ (in LONDON) versus the $\mathrm{PM}_{2.5}$ concentrations determined by the filter sampling. Factors (slopes) equals to 1.44 ( $\mathrm{r} 2=0.82$; gravimetric versus DMA-volume) at MILAN, 
Table 1. Aerosol number $(\mathrm{N})$ and mass $\left(\mathrm{PM}_{2.5}\right)$ concentrations statistic at MILAN (November 2003-December 2004), BARCELONA (November 2003-December 2004) and LONDON (April 2004-April 2005 for PM 2.5 and January-December 2003). DpN, DpS, DpV: mode of the number, surface and volume size distribution. $\mathrm{m} 1$ : mode of the mean size distribution, $\mathrm{m} 2$ and med.: mean and median of all hourly values of the size distribution modes. ND: number of daily mean data used for the calculations. ${ }^{1} \mathrm{PM}_{2.5}$ : values calculated from sampling on filter, ${ }^{2} \mathrm{PM}_{2.5}$ : values computed from continuous measurements after correcting for gravimetric equivalence.

\begin{tabular}{|c|c|c|c|c|c|c|c|c|c|}
\hline & MILAN & & & BARCELO & NA & & LONDON & & \\
\hline $\mathrm{N}$ & $\mathrm{cm}^{-3}$ & & $\%$ & $\mathrm{~cm}^{-3}$ & $\%$ & & $\mathrm{~cm}^{-3}$ & & $\%$ \\
\hline $10-800$ & 25833 & & & 16811 & & & & & \\
\hline $10-415$ & 25676 & & 99 & 16759 & 99 & & 11409 & & \\
\hline 10-20 & 2455 & & 10 & 1941 & 12 & & 1348 & & 12 \\
\hline $20-30$ & 4145 & & 16 & 3386 & 20 & & 1986 & & 17 \\
\hline $30-50$ & 5634 & & 22 & 3988 & 24 & & 2693 & & 24 \\
\hline $50-100$ & 8365 & & 32 & 5093 & 30 & & 3302 & & 29 \\
\hline $100-200$ & 3795 & & 15 & 1855 & 11 & & 1601 & & 14 \\
\hline $200-415$ & 1283 & & 5 & 496 & 3 & & 475 & & 4 \\
\hline $415-800$ & 157 & & $<1$ & 49 & $<1$ & & & & \\
\hline $\mathrm{nm}$ & $\mathrm{m} 1$ & $\mathrm{~m} 2$ & med & $\mathrm{m} 1$ & $\mathrm{~m} 2$ & med & $\mathrm{m} 1$ & $\mathrm{~m} 2$ & med \\
\hline DpN & 36 & 47 & 41 & 36 & 39 & 36 & 38 & 50 & 43 \\
\hline $\mathrm{DpS}$ & 233 & 213 & 179 & 179 & 178 & 179 & 198 & 228 & 198 \\
\hline $\mathrm{DpV}$ & 309 & 340 & 309 & 309 & 294 & 309 & 437 & 355 & 379 \\
\hline$\mu \mathrm{g} / \mathrm{m}^{3}$ & ND & mean & 90th & ND & mean & 90th & ND & mean & 90th \\
\hline${ }^{1} \mathrm{PM}_{2.5}$ & 96 & 47 & 87 & 94 & 34 & 55 & 63 & 31 & 45 \\
\hline${ }^{2} \mathrm{PM}_{2.5}$ & 264 & 45 & 81 & 365 & 26 & 40 & 362 & 20 & 33 \\
\hline
\end{tabular}

$1.45\left(r^{2}=0.75\right.$; gravimetric versus OPC $)$ at BARCELONA and $1.62\left(\mathrm{r}^{2}=0.74\right.$; gravimetric versus $\left.\mathrm{TEOM}^{\mathrm{TM}}\right)$ at LONDON were obtained. These factors (slopes) are not directly comparable, as different techniques were used for the continuous aerosol measurements (x-axis values) at each site.

At MILAN and BARCELONA, these measurements were performed from November 2003 to December 2004. At LONDON, the number size distribution was measured from January to December 2003, whereas the chemical characterization was performed from April 2004 to April 2005.

\section{Results and discussion}

The results are presented in several specific sections focussing the main questions that prompted this study. Some of the figures that will be shown in the following sections provide a high density of information due to the avoidance of data reduction resulting in information loss. The discussion will focus only on the most relevant points and mainly on aerosol features common at the three sites.

\subsection{Mean physical properties}

Table 1 and Fig. 2 show the mean $\mathrm{PM}_{2.5}$ and number concentrations, as well as the mean size distributions at the three study sites. Annual mean concentrations of $\mathrm{PM}_{2.5}$, $\mathrm{N}>10(\mathrm{~nm})$ and N10-100 at the three sites are within the range of typical values across Western Europe (Ruuskanen et al., 2001; Van Dingenen et al., 2004), $\mathrm{PM}_{2.5}$ : 20 $45 \mu \mathrm{g} / \mathrm{m}^{3}, \mathrm{~N}>10(\mathrm{~nm}): 10-25 \times 10^{3} \mathrm{~cm}^{-3}$ and $\mathrm{N} 10-100$ : $10-20 \times 10^{3} \mathrm{~cm}^{-3}$. N10-415 accounts for $\sim 99 \%$ of $\mathrm{N}>10$ $(\mathrm{nm})$, whereas the ultrafine fraction N10-100 accounts for $80-85 \%$ of $\mathrm{N}>10(\mathrm{~nm})$ at the 3 sites. The MILAN \& BARCELONA to LONDON ratios for $\mathrm{PM}_{2.5}, \mathrm{~N}>10(\mathrm{~nm})$ and N10-100 are equal to $2.3,2.2,2.3$ and 1.3, 1.5, 1.5, respectively. The mode of the number (DpN: $\sim 37 \mathrm{~nm})$; surface (DpS: $180-230 \mathrm{~nm})$ and volume (DpV: $300-440 \mathrm{~nm})$ size distributions exhibits the well known displacement toward coarser fractions.

\subsection{Mean chemical composition}

Table 2 shows the mean chemical composition of $\mathrm{PM}_{2.5}$. The "most to less" important $\mathrm{PM}_{2.5}$ contributors are: 1) $\mathrm{OM}$ $\left(28-31 \%\right.$ of $\left.\left.\mathrm{PM}_{2.5}\right), 2\right) \mathrm{NO}_{3}^{-}$at MILAN $(21 \%)$ \& LONDON (11\%) and nss-SO $=$ at BARCELONA (14\%), 3) nss$\mathrm{SO}_{4}^{=}$at MILAN (10\%) \& LONDON (9\%) and $\mathrm{NO}_{3}^{-}$at BARCELONA (10\%), 4) $\mathrm{NH}_{4}^{+}(10 \%$ at MILAN and 6-7\% at BARCELONA \& LONDON), and 5) BC (6-7\%). Mineral dust concentrations are much higher at BARCELONA $\left(4.6 \mu \mathrm{g} / \mathrm{m}^{3}\right)$ than at the other sites $\left(1.7 \mu \mathrm{g} / \mathrm{m}^{3}\right.$ at MILAN \& 


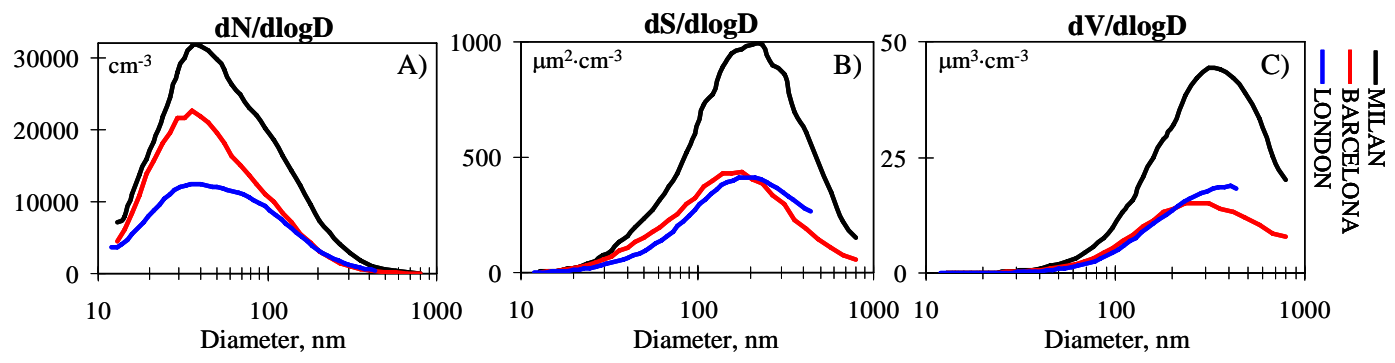

Fig. 2. Mean size distribution of aerosol number, surface and volume concentrations during the 1-year study period.

Table 2. Statistic of $\mathrm{PM}_{2.5}$ composition based on 96, 94 and 65 samples collected in MILAN, BARCELONA and LONDON from December 2003 to December 2004, December 2003 to December 2004, and April 2004 to April 2005, respectively. Trace elements: sum of Zn, V, Cr, $\mathrm{Co}, \mathrm{Ni}, \mathrm{Cu}, \mathrm{As}, \mathrm{Cd}$ and $\mathrm{Pb}$.

\begin{tabular}{|c|c|c|c|c|c|c|c|c|c|}
\hline & \multicolumn{3}{|c|}{ MILAN } & \multicolumn{3}{|c|}{ BARCELONA } & \multicolumn{3}{|c|}{ LONDON } \\
\hline & $\begin{array}{l}\text { mean } \\
\mu \mathrm{g} / \mathrm{m}^{3}\end{array}$ & $\%$ & $\begin{array}{l}90 \text { th } \\
\mu \mathrm{g} / \mathrm{m}^{3}\end{array}$ & $\begin{array}{l}\text { mean } \\
\mu \mathrm{g} / \mathrm{m}^{3}\end{array}$ & $\%$ & $\begin{array}{l}\text { 90th } \\
\mu \mathrm{g} / \mathrm{m}^{3}\end{array}$ & $\begin{array}{l}\text { mean } \\
\mu \mathrm{g} / \mathrm{m}^{3}\end{array}$ & $\%$ & $\begin{array}{l}\text { 90th } \\
\mu \mathrm{g} / \mathrm{m}^{3}\end{array}$ \\
\hline $\mathrm{PM}_{2.5}$ & 47.0 & & 86.8 & 34.3 & & 54.5 & 31.0 & & 45.5 \\
\hline $\mathrm{OM}$ & 14.8 & 31 & 32.3 & 9.7 & 28 & 14.8 & 9.0 & 29 & 14.3 \\
\hline $\mathrm{BC}$ & 1.8 & 4 & 2.9 & 1.9 & 6 & 2.8 & 1.6 & 5 & 2.5 \\
\hline $\mathrm{NO}_{3}^{-}$ & 10.1 & 21 & 23.4 & 3.5 & 10 & 8.0 & 3.5 & 11 & 9.3 \\
\hline$n s s-\mathrm{SO}_{4}^{=}$ & 4.6 & 10 & 8.4 & 4.6 & 14 & 9.1 & 2.8 & 9 & 5.5 \\
\hline $\mathrm{NH}_{4}^{+}$ & 4.8 & 10 & 10.0 & 2.2 & 6 & 4.7 & 2.1 & 7 & 5.9 \\
\hline $\mathrm{OM}+\mathrm{BC}$ & 16.5 & 35 & 34.7 & 11.6 & 34 & 18.1 & 10.6 & 34 & 15.7 \\
\hline SIC & 19.4 & 41 & 39 & 10.4 & 30 & 20 & 8.4 & 27 & 21.0 \\
\hline Mineral & 1.7 & 4 & 3 & 3.7 & 11 & 8 & 0.6 & 2 & 0.9 \\
\hline Sea-salt & 0.2 & 0.4 & 0.4 & 0.7 & 2.2 & 1 & 0.7 & 2.1 & 1.7 \\
\hline Trace & 0.1 & 0.2 & 0.2 & 0.1 & 0.4 & 0 & 0.04 & 0.1 & 0.1 \\
\hline$\sum$ chemistry & 38 & & & 27 & & & 20 & & \\
\hline$\%$ Determined & 81 & & & 77 & & & 66 & & \\
\hline
\end{tabular}

$0.6 \mu \mathrm{g} / \mathrm{m}^{3}$ at LONDON), whereas nss-SO $=$ concentrations are much lower in LONDON $\left(2.8 \mu \mathrm{g} / \mathrm{m}^{3}\right)$ than in the other sites $\left(4.6 \mu \mathrm{g} / \mathrm{m}^{3}\right)$.

The difference of the concentrations of $\mathrm{PM}_{2.5}$, $\mathrm{NO}_{3}^{-}$, OM and $\mathrm{NH}_{4}^{+}$"Milan minus Barcelona" $(\Delta)$ and "Milan minus London" $(\Delta)$ fit very well to the equation: " $15 \mu \mathrm{g} \Delta \mathrm{PM}_{2.5} / \mathrm{m}^{3}=7.0 \mu \mathrm{g} \Delta \mathrm{NO}_{3}^{-} / \mathrm{m}^{3}$ $+5.5 \mu \mathrm{g} \Delta \mathrm{OM} / \mathrm{m}^{3}+2.5 \mu \mathrm{g} \Delta \mathrm{NH}_{4}^{+} / \mathrm{m}^{3}$ " (for each of these differences: "Milan-Barcelona" and "MilanLondon"). This indicates that the $\mathrm{PM}_{2.5}$ concentrations at Milan are $15 \mu \mathrm{g} / \mathrm{m}^{3}$ higher than in Barcelona or London because of a mean contribution of $7.0 \mu \mathrm{gNO}_{3}^{-} / \mathrm{m}^{3}+5.5 \mu \mathrm{gOM} / \mathrm{m}^{3}+2.5 \mu \mathrm{gNH}_{4}^{+} / \mathrm{m}^{3}$.

\subsection{Aerosol daily evolution}

The processes involved in the daily evolution of aerosols have been studied by performing the following analyses: 1) the daily evolution of the hourly mean values of the "road traffic intensity", "primary trace gases concentrations $(\mathrm{CO}$, $\mathrm{NO}_{\mathrm{x}}$ and $\mathrm{SO}_{2}$ )" and "several aerosols parameters (including the size distribution mode, mass concentrations and number concentration in several size ranges)" during every day of the week (Fig. 3, note: gases are not include in this graph); 2) calculation of the ratio increase in the aerosol concentrations from the "nocturnal background (02:00-05:00)" to the "morning rush hours (06:00-08:00)" and to the whole "daylight period (06:00-18:00)" for the mass concentrations and for the number concentrations in several size ranges (Fig. 4); 3) calculation of the correlation coefficient between the weekly evolution of the concentrations of aerosol mass, aerosol number (in several size ranges) and trace gases linked to combustions emissions (Fig. 5). The following discussion is based on the results plotted in Figs. 3-5.

All metrics of the aerosol concentration exhibit a maximum during the morning rush hours of the working days due to vehicles exhaust emissions (Figs. 3a-c). These road traffic emissions result in a higher night-to-morning increase in 

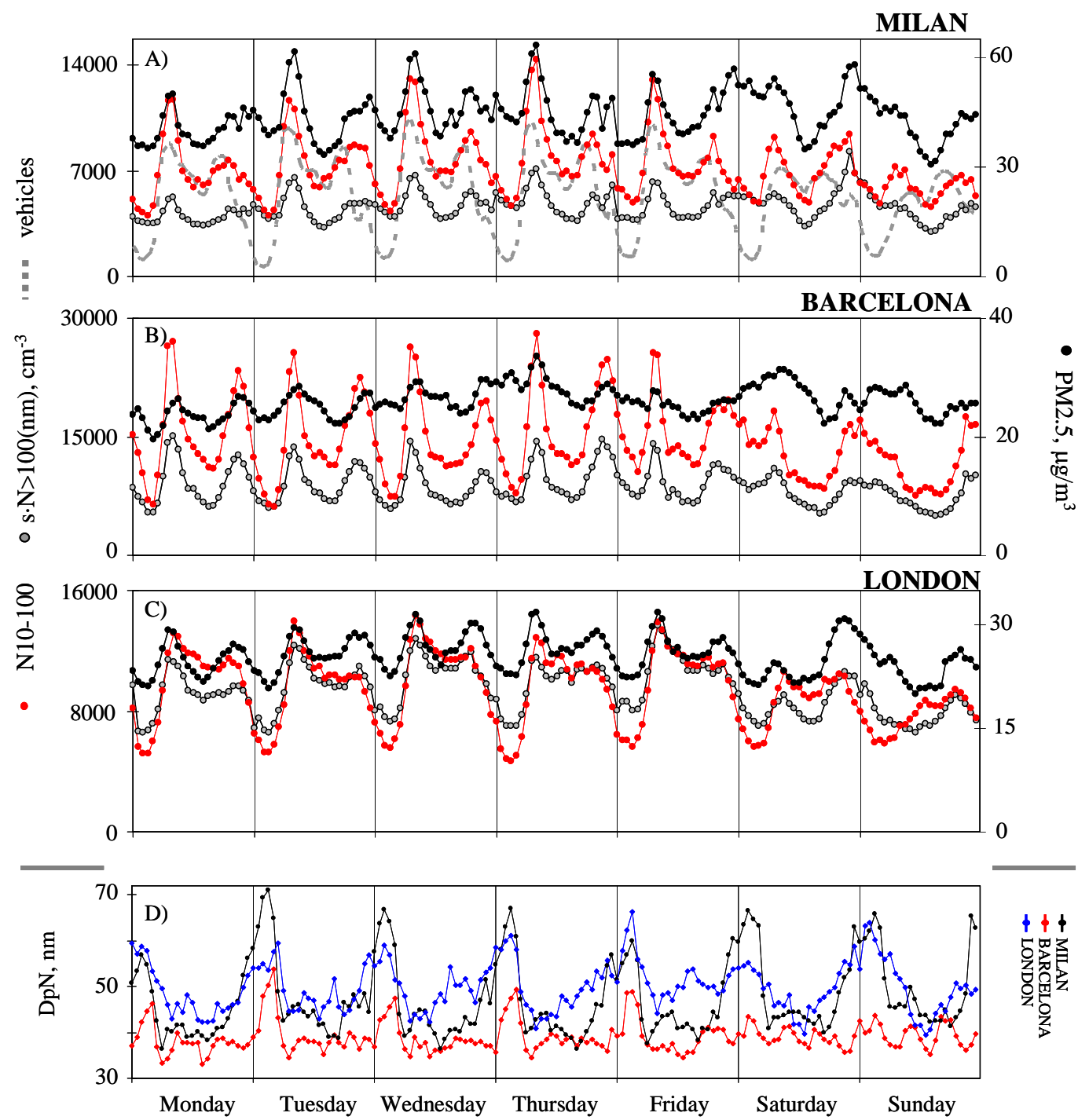

Fig. 3. Hourly mean values of the road traffic intensity (only at MILAN), the particles size distribution mode (DpN) and number N10-100, $\mathrm{N}>100(\mathrm{~nm})$ and mass $\mathrm{PM}_{2.5}$ concentrations. The number concentration $\mathrm{N}>100(\mathrm{~nm})$ is multiplied by a scale factor, $\mathrm{s}=2$ at $\mathrm{MILAN},=3$ at BARCELONA and $=2$ at LONDON. These averages are based on 1-year data.

the concentrations of ultrafine $(<100 \mathrm{~nm})$ than the $>100 \mathrm{~nm}$ particles (Fig. 4). Observe in Fig. 4A1 how the "morningrush hours" to "nocturnal-background" concentrations ratio is $1.5-3.0$ for particles $<50 \mathrm{~nm}$ and $\leq 1.5$ for particles $>200 \mathrm{~nm}$. The same trend is observed for the increase from the "nocturnal-background" to the whole "daylight period" (Fig. 4B1). The DpN particle diameter (dN/dlogD mode) exhibits values within the ranges $30-45 \mathrm{~nm}$ during daylight and $50-70 \mathrm{~nm}$ at night (Fig. 3c). This daily evolution is the result of: 1) an abrupt DpN decrease in the morning because the sharp increase in vehicles exhausts emissions, 2) low DpN values during daylight owing to the contribution of photochemical nucleation particles, evaporation of semi-volatile compounds from the particle's surface and the vehicle emissions (with a lower intensity than in the morning) and 3) a strong nocturnal DpN increase due to the lack of significant emissions, particle growth because the effects of particles coagulation and condensation of semi-volatile species onto pre-existing particles. The daylight-to-night change in the ambient conditions influences this DpN daily evolution, by favouring evaporation during daylight (due to the increase in temperature and to the decrease of the gas-phase precursors concentrations owing to the dilution induced by the higher boundary layer depth; Fig. 1e) and condensation at night (due to ambient conditions opposites to the diurnal ones). Particle growth by coagulation in short time scales ( hours) is considered to be the most important process prompting the low residence time of particles $(<50 \mathrm{~nm})$ that were observed, and contribute to the above cited (Fig. 4) high "morning rush hours" and "daylight" to "nocturnal-background" 
concentrations ratios. After the evening rush hours, the number concentrations N10-20 and N10-100 experience a much more important decrease than $\mathrm{N}>100(\mathrm{~nm})$ owing to: 1$)$ the growth of particles with an initial size $<100 \mathrm{~nm}$ contributing to $\mathrm{N}>100$ (nm), and 2) coagulation is not as important contributing factor for particles $>100 \mathrm{~nm}$. Moreover, deposition prompted by Brownian diffusion may also contributed significantly to decrease the number concentration of $<50 \mathrm{~nm}$ particles, as shown by Gidhagen et al. (2005) during a modelling study in Stockholm.

The results from the current study are in agreement with other studies on aerosols "vehicles emissions" and "observations in urban ambient air". Studies on "emissions" have shown that, although the particles size distribution due to the vehicles exhauss emissions may experience variations (depending on the type of engine, fuel, lubricant and technology of the emissions control applied), they all tend to exhibit a main mode within the range $10-30 \mathrm{~nm}$ and other "carbonaceous mode" within the range 50-200 nm (Kittelson, 1998; Harris and Maricq 2001; Casati et al., 2007). Being the main mode $(10-30 \mathrm{~nm})$ attributed to the nucleation of sulphuric acid and some organic compounds during the emission, dilution and cooling of the exhaust. These exhaust emissions are considered to be one of the major factors because the "morning rush hours-to-night" concentrations ratio reach maximum values within the particle diameter range $<50 \mathrm{~nm}$, and exhibits a decreasing trend when increasing the particle diameter (Fig. 4A1). Other studies on "urban aerosol observations in ambient air" performed in Central and Northern European cities, such as Leipzig (Wehner et al., 2002; Wehner and Widensohler, 2003), Copenhagen (Ketzel et al., 2004) and Helsinki (Hussein et al., 2004), have also described the "working days-to-weekends" changes in the aerosol daily evolution and shifts in the size distribution detected, at Milan, Barcelona and London, in the current study.

This analysis of the urban aerosol in the 3 study cites shows that:

1) the ultrafine particles N10-100 concentrations are much more sensitive to the "fresh vehicle exhaust emissions" than $\mathrm{PM}_{2.5}$. This is also valid for the total number concentration $\mathrm{N}>10(\mathrm{~nm})$ due to the ultrafine fraction N10-100 accounting for a very high portion of $\mathrm{N}>10(\mathrm{~nm})(80-85 \%)$. Observe in Figs. 5B1-5D1 and 5B3-5D3 how N10-100 and N>10 (nm) exhibits a much higher correlation coefficient with the fresh N10-20 particles than with $\mathrm{PM}_{2.5}$ and $\mathrm{N}>100(\mathrm{~nm})$.

2) the daily evolution of $\mathrm{PM}_{2.5}$ is mainly modulated by the variations in the number concentrations of $N>100$ $(\mathrm{nm})$. These variations in $\mathrm{PM}_{2.5}$ and $\mathrm{N}>100(\mathrm{~nm})$ are smoother than those of the ultrafine particles because particles $>100 \mathrm{~nm}$ are mostly linked to the urban background aerosol. Observe in the Figs. 5A1 and 5A3 how the weekly evolution of $\mathrm{PM}_{2.5}$ is much better correlated with that of $\mathrm{N}>100(\mathrm{~nm})$ than with that of dominant ultrafine N10-100 particles (Fig. 5), and in Fig. 3 how the above description for the particles $>100 \mathrm{~nm}$ applies for $\mathrm{PM}_{2.5}$ as well. This is at-

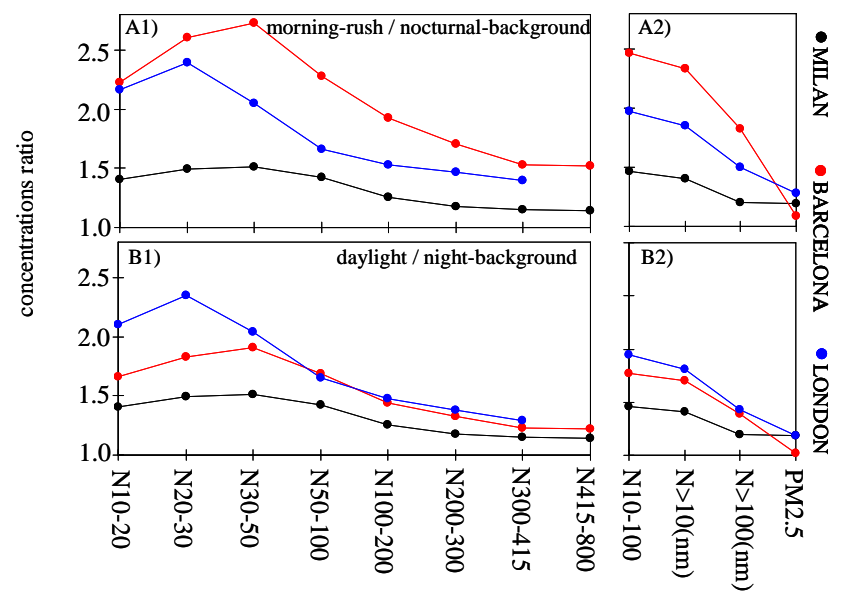

Fig. 4. "Morning rush hours (06:00-08:00) to nocturnalbackground (02:00-05:00)" and "daylight (06:00-18:00) to nightbackground (02:00-05:00)" ratios of the aerosol $\mathrm{PM}_{2.5}$ mass and number concentration in several size ranges during working days of the 1-year study period.

tributed to the fact that particles $>100 \mathrm{~nm}$ contribute to the aerosol mass and volume to a greater extent than ultrafine particles (even though the later accounts for $80-85 \%$ of the total number of fine particles; Fig. 1).

3) the daily evolution of $\mathrm{CO}$ and $\mathrm{NO}_{\mathrm{x}}$ (mainly controlled by vehicle exhaust emissions) correlates better with that of $\mathrm{N}>10(\mathrm{~nm})$ and $\mathrm{N} 10-100$ than with that of $\mathrm{PM}_{2.5}$ (Figs. 5A2-5D2), as vehicles exhausts mostly emit ultrafine particles.

4) only at LONDON there is a significant correlation between the daily evolutions of $\mathrm{SO}_{2}$ and particles number concentrations (Figs. 5A2-5D2). This is probably due to the influence of other "non-vehicle exhaust emissions" sources on the $\mathrm{SO}_{2}$ daily evolution in MLAN and BARCELONA (e.g. power and industrial plants present in those cities).

\section{$4.4 \quad \mathrm{PM}_{2.5}$ events}

Figure 6 shows the "daily mean concentrations of $\mathrm{PM}_{2.5}$ and its most important contributors", and the "hourly mean values of the aerosol size distribution mode $(\mathrm{DpN})$, aerosol mass $\mathrm{PM}_{2.5}$ concentrations and aerosol number concentration in several size ranges" recorded during the whole study period. The objective of this section is to identify the microphysical processes involved in the day-to-day changes of the aerosol features. For this purpose, the following analysis was applied to the data plotted in Fig. 6: 1) the occurrence of "urban PM pollution episodes", "Saharan dust outbreaks" and "clean air events" were identified on the basis of the meteorology coupled with analysing the time series of several aerosol parameters (as described in Rodríguez et al., 2005; see some examples in Fig. 7); 2) the mean chemical composition and daily evolution of aerosols during events of 

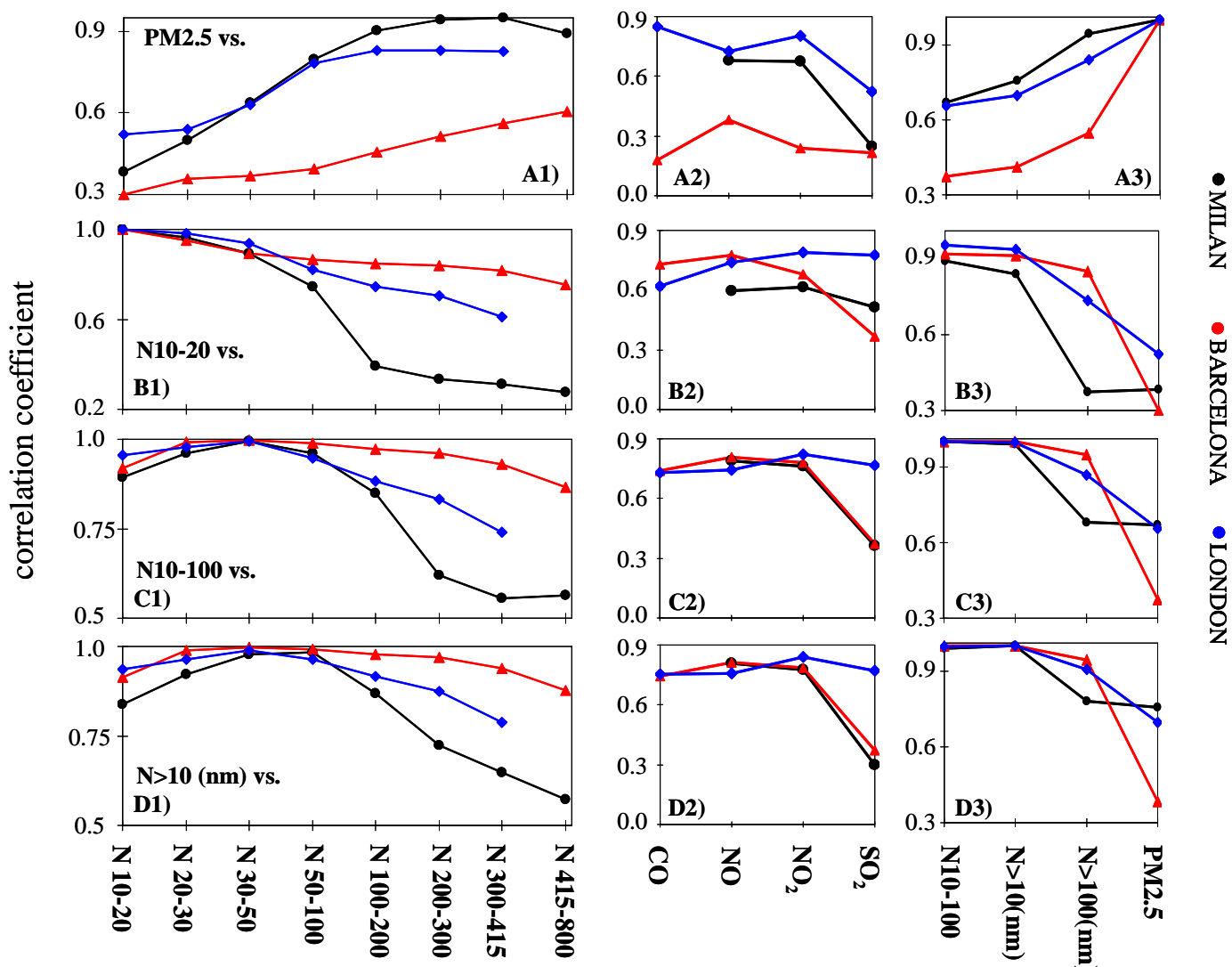

and those of "the aerosol $\mathrm{PM}_{2.5}$ mass, number concentrations (in several size ranges) and gases".

low $\left(\mathrm{PM}_{2.5}<30\right.$ th-percentile), mid (30th $<\mathrm{PM}_{2.5}<80$ th) and high $\left(\mathrm{PM}_{2.5}>80\right.$ th) mass $\mathrm{PM}_{2.5}$ concentrations was studied (Fig. 8).

As expected, "low PM - clean air episodes" mostly occurred during high wind speed events, frequently associated with air masses renovation linked to cold front passages. "PM pollution episodes" were favoured by weak barimetric gradient conditions and anticyclonic situations, frequently associated with winter inversion layers near the ground at MILAN. "Saharan dust transport" occurred under other well known meteorological scenarios.

\subsubsection{Urban PM pollution events}

During periods dominated by concatenations of "urban pollution events" and "clean air-low PM episodes", the daily mean $\mathrm{PM}_{2.5}$ and $\mathrm{DpN}$ time series show significant correlated variations, indicating that $\mathrm{PM}_{2.5}$ is made up of coarser particles during "pollution events" than under "clean air conditions". Figure 7 (where the types of events are highlighted) shows some examples from the three studied cities, where it can be observed how DpN increases from 30 to $\sim 65 \mathrm{~nm}$ are associated with $\mathrm{PM}_{2.5}$ increases from 20 to $80 \mu \mathrm{g} / \mathrm{m}^{3}$ at MILAN \& BARCELONA and to $50 \mu \mathrm{g} / \mathrm{m}^{3}$ at LONDON, from "clean air" to "urban pollution" events. Observe in Fig. 8 (where the mean chemical composition and daily evolution of aerosols under different pollution degrees is shown) how the increase in the aerosol $\mathrm{PM}_{2.5}$ mass concentrations throughout the sequence "low-mid-high" levels is associated with an increase in the nocturnal DpN values, leaving the diurnal $\mathrm{DpN}$ values relatively constant throughout the sequence. This indicates that an increase in the aerosol $\mathrm{PM}_{2.5}$ mass concentrations is associated with an enhancement in the nocturnal particle growth described above ("daily evolution" section). A detailed event-to-event analysis corroborates this simultaneous $\mathrm{DpN}$ and $\mathrm{PM}_{2.5}$ correlated increases at night during $\mathrm{PM}_{2.5}$ episodes (examples of episodes not shown for the sake of brevity).

Although both "particle coagulation" and "condensation of semi-volatile species onto pre-existing particles" may contribute to this nocturnal particle growth just as described above (Figs. 8a to c), only condensation may accounts for the observed simultaneous increase in the particle's DpN diameter and mass $\mathrm{PM}_{2.5}$ concentrations. This condensation of semi-volatile species is enhanced when temperature decreases (e.g. winter vs. summer or night vs. daylight) and when reducing the "boundary layer depth" and "wind speed". 

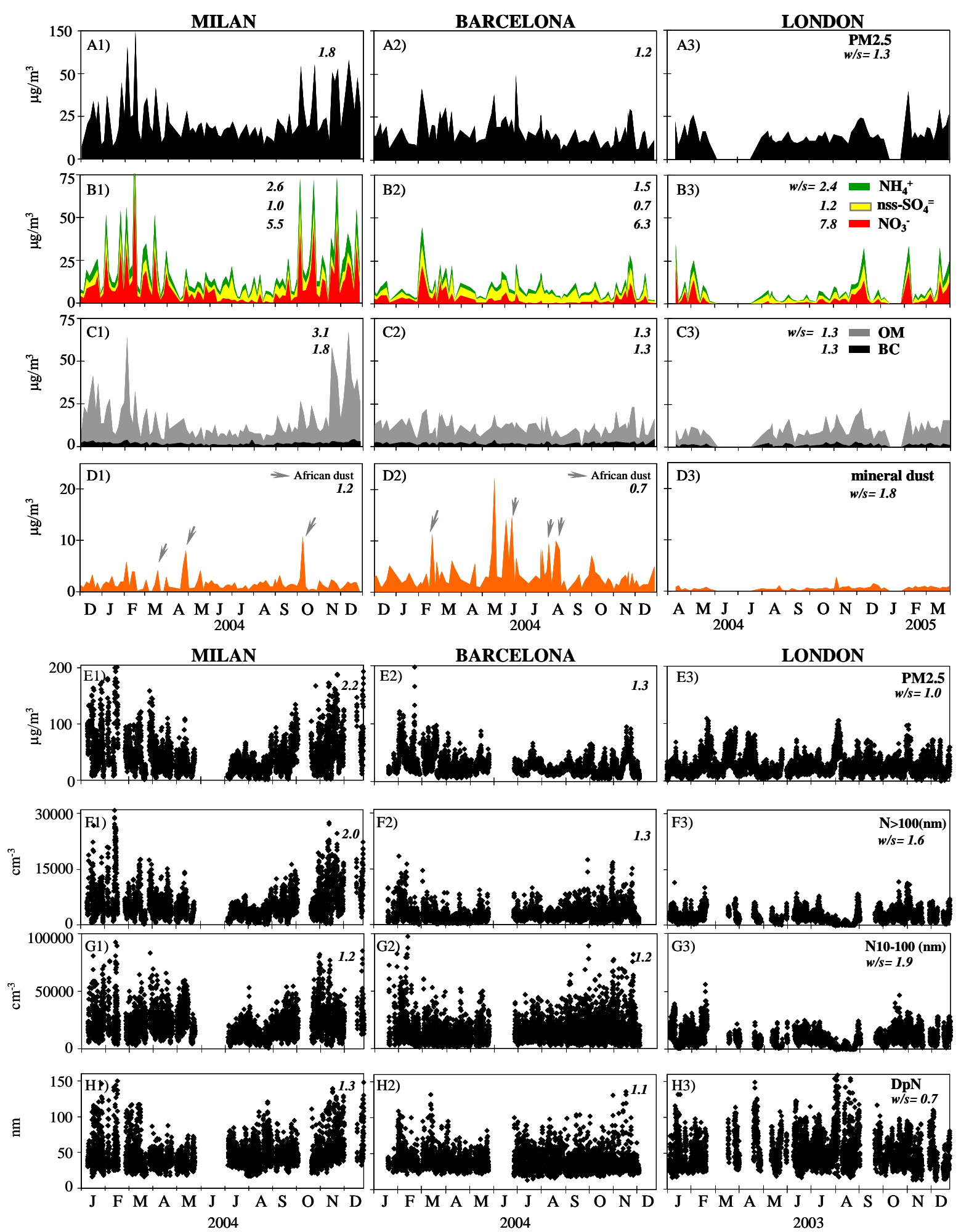

Fig. 6. Daily mean concentrations of $\mathrm{PM}_{2.5}$ and including its major contributors (A-D) and hourly mean concentrations of $\mathrm{PM}_{2.5}$ and the aerosol-number concentration in several size ranges $(\mathbf{E}-\mathbf{J})$. w/s = mean winter (November-February)/summer (May-August) concentrations ratio. 


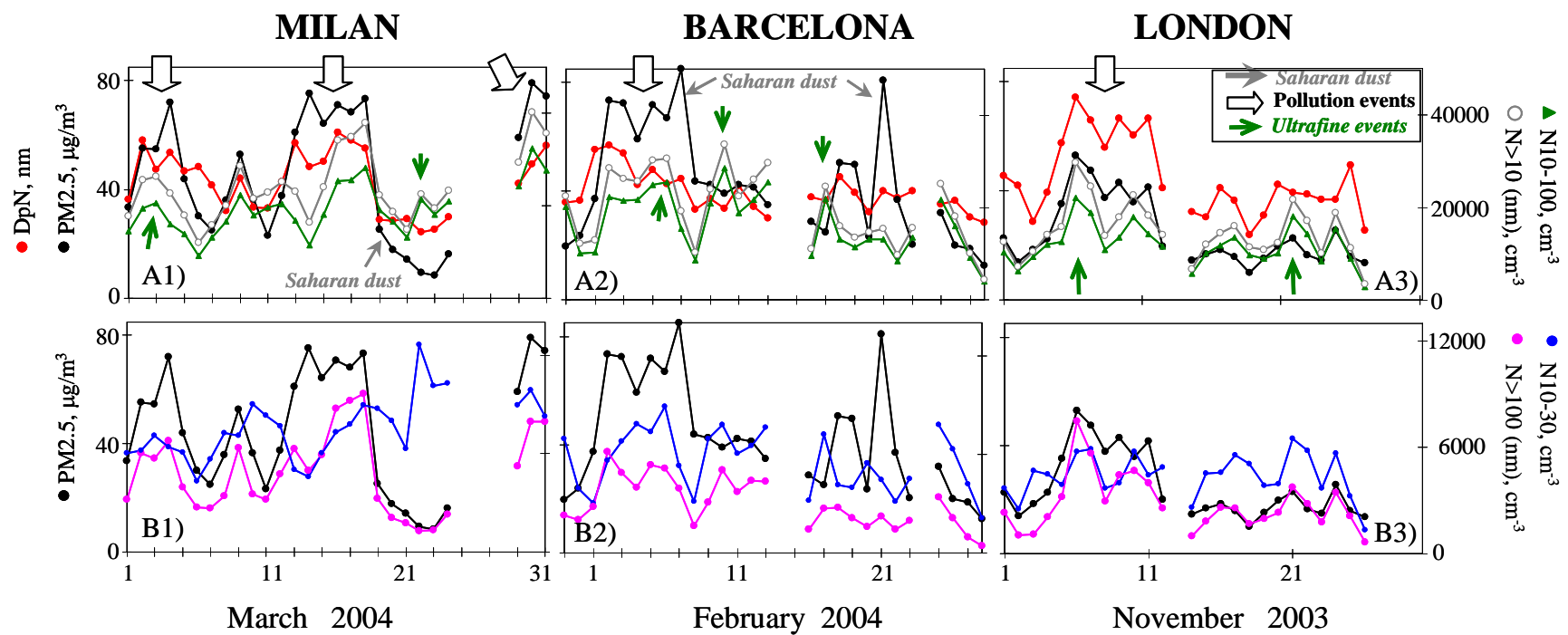

Fig. 7. Daily mean values of the aerosol $\mathrm{PM}_{2.5}$ mass concentrations, number concentrations (in several size ranges) and size distribution mode (DpN) at the 3 study cities during selected periods when different types of aerosol episodes took place. Events of "Saharan dust", "urban pollution" and "ultrafine particles" are highlighted (previous identification was performed by using the methodology described in Rodríguez et al. (2005) and references therein).

This second case occurs because the lower dilution increases the concentration of gas-phase precursors favouring that these compounds easily exceed the equilibrium vapour pressure, i.e. supersaturation. The study data indicates that condensation onto pre-existing particles of ammonium-nitrate at the three study sites (and some OM species at MILAN) are strongly involved in the particle growth from the "mid" to "high" $\mathrm{PM}_{2.5}$ events (when the highest "daylight-to-night" $\mathrm{DpN}$ increase is observed; Fig. 8c) at the three study sites. This is supported by the following observations (Fig. 8):

1) ammonium and nitrate are the compounds exhibiting the highest increase from "mid" to "high" $\mathrm{PM}_{2.5}$ episodes at the three sites, with "high/mid concentration" ratios $=4.5$ and 2.9 at MILAN \& LONDON, and $=3.5$ and 2.5 at BARCELONA for nitrate and ammonium, respectively, and $<2$ for the other major components (except for OM at MILAN). This nocturnal formation of ammonium-nitrate, that would increase the particle diameter by condensation, has already been documented (Weber et al., 2001; Alastuey et al., 2004).

2) the increase in the concentrations of OM from "mid" to "high" $\mathrm{PM}_{2.5}$ episodes is much higher than that of $\mathrm{BC}$ at MILAN ("high/mid" events ratios=3.1 for $\mathrm{OM}$ and 1.5 for $\mathrm{BC}$ ) than at BARCELONA (1.5 for OM and 1.2 for $\mathrm{BC}$ ) and LONDON (1.4 for OM and 1.1 for BC). Because the BC (a primary particle) increase is mainly attributed to the lower dilution during pollution episodes (because the lower "boundary layer depth"), the much higher OM increase at MILAN is attributed to condensation processes (secondary OM formation).
These results showing how the size distribution mode tend to increase when increasing the ammonium-nitrate and organic matter concentrations in $\mathrm{PM}_{2.5}$, provides a complementary view on the urban PM pollution events usually registered in winter across Europe (Putaud et al., 2004; Querol et al., 2004).

\subsubsection{Saharan dust events}

Although this study is not focused on characterising Saharan dust, this brief analysis have been included because the interest of Saharan dust transport as an air quality impairment agent. In southern Europe, it has been observed that these Saharan events result in high $\mathrm{PM}_{10}$ concentrations (Rodríguez et al., 2006). This new data set provides a good opportunity to compare the Saharan dust inputs to $\mathrm{PM}_{2.5}$ in northern and southern regions of Western Europe.

The Saharan dust contributions to $\mathrm{PM}_{2.5}$ levels are highlighted in Fig. 6d: 4 events occurred in BARCELONA (over 94 filter samples), 3 events in MILAN (96 samples) and zero events in LONDON (65 samples). Mineral dust concentrations during these Saharan dust episodes were into the ranges $8-15 \mu \mathrm{g} / \mathrm{m}^{3}$ in BARCELONA and $4-11 \mu \mathrm{g} / \mathrm{m}^{3}$ in MILAN. These dust events did not resulted in any specific variation (or "signature") in the particles size distribution or number concentration. This is attributed to the fact that Saharan dust is present in much lower number concentrations than the urban aerosols, although it exhibits high mass concentrations in the supermicron fraction (because of its relatively high density). Observe in the Figs. 7A2-7B2 how during the Saharan dust events, the aerosol $\mathrm{PM}_{2.5}$ mass concentrations experienced a 

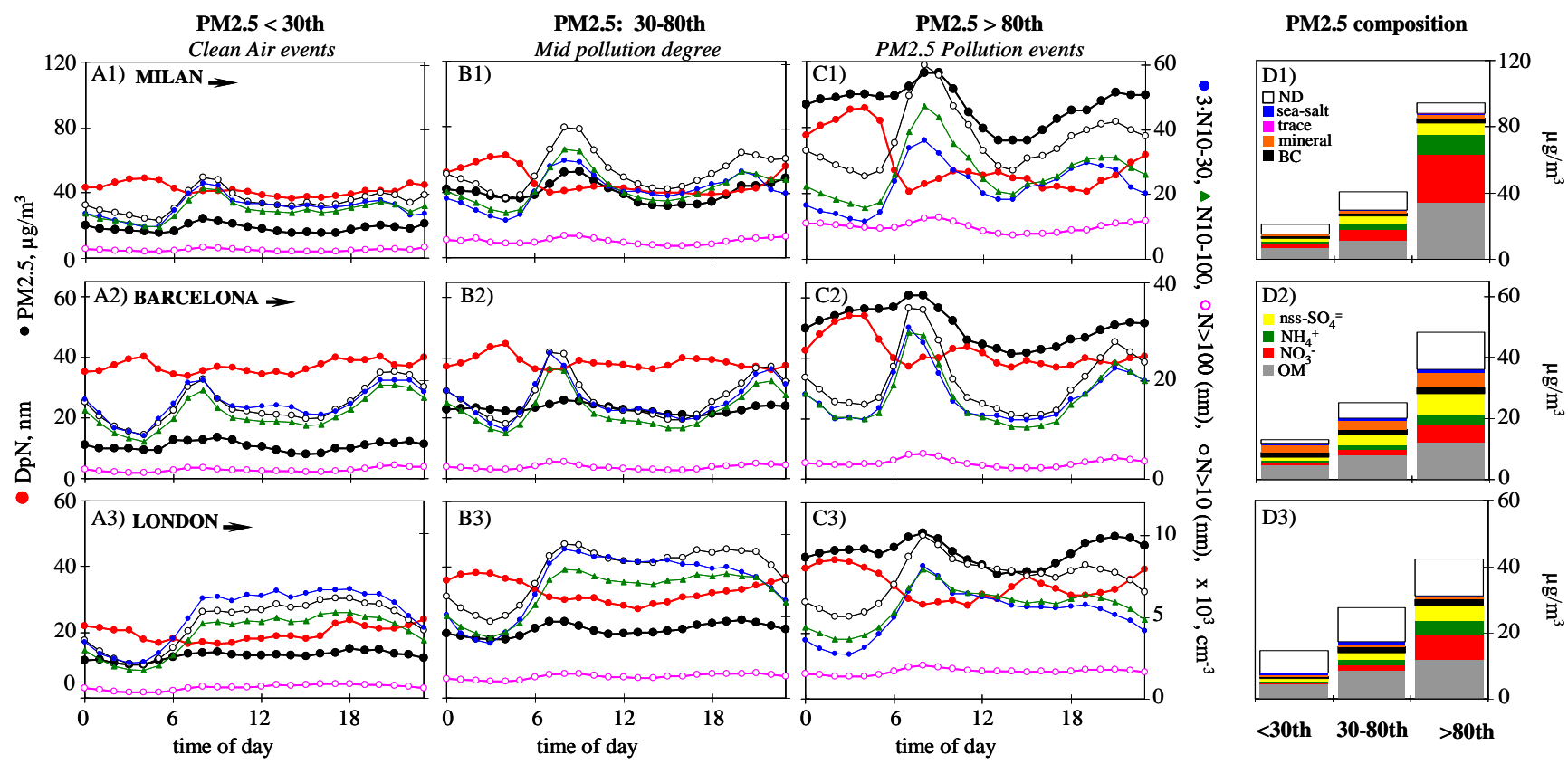

Fig. 8. Daily mean evolution of several aerosol parameters (A-C) and mean $\mathrm{PM}_{2.5}$ aerosol chemical composition during events of "low (<30th percentile)", "mid (30-80th percentile)" and "high (>80th percentile)" $\mathrm{PM}_{2.5}$ concentrations in the 3 study sites. Panels (D): "ND"=Non-Determined $\left(\mathrm{PM}_{2.5}\right.$ - sum of chemistry), "trace" = trace elements (see Table 2), "mineral" = Mineral dust.

strong increase without any significant change in the number concentration.

\subsection{Seasonal evolution}

Some of the $\mathrm{PM}_{2.5}$ chemical components exhibited features observed commonly across Europe (Figs. 6): 1) BC, OM and $\mathrm{NO}_{3}^{-}$levels maximises in winter, 2) nss- $\mathrm{SO}_{4}^{=}$exhibits higher background levels and a higher relative contribution in summer, and 3) nss- $\mathrm{SO}_{4}^{=}$and $\mathrm{NO}_{3}^{-}$mainly occur as ammonium salts (ionic balance analysis not shown). Moreover, the number concentration in all size ranges exhibits higher levels in winter than in summer (only shown for $\mathrm{N}<100 \mathrm{~nm}$ and $\mathrm{N}>100$ (nm) in Fig. 6). This winter maximum in the particles "number concentration" and in the "mass $\mathrm{BC}, \mathrm{OM}, \mathrm{NO}_{3}^{-}$and $\mathrm{NH}_{4}^{+}$concentrations" is prompted by several mechanisms favouring "condensation" and "nucleation of the fresh vehicle exhaust emissions", such as: 1) concentration of particles and its gaseous precursors due to the lower "dilution" prompted by the "lower boundary layer depth"; 2) lower temperatures that reduce the "equilibrium vapour pressure". This enhancement of the "condensation" processes in winter result in the " $\mathrm{PM}_{2.5}$ mass events" described above, characterised by an increase in the "concentrations of $\mathrm{PM}_{2.5}$ and $\mathrm{N}>100$ (nm)" and in the "DpN size distribution" (Figs. 6, 7 and 8). In winter, $\mathrm{OM}$ and ammonium-nitrate were the most important $\mathrm{PM}_{2.5}$ contributors; accounting for $75 \%, 50 \%$ and $47 \%$ of $\mathrm{PM}_{2.5}$ mass in winter (November-February) and $32 \%, 25 \%$ and $34 \%$ of $\mathrm{PM}_{2.5}$ in summer (June-August) at
MILAN, BARCELONA \& LONDON, respectively. Conversely, the increase in the number concentration due to an enhancement of the "nucleation rates in vehicles exhaust" when decreasing the temperature has been observed both in "emissions" and in "ambient air" studies. Casati et al. (2007) observed how the nucleation mode particle number concentrations in the "vehicles exhaust" increases when decreasing the temperature. This is in agreement with Gidhagen et al. (2005) who observed, in Stockholm, that the slope of the particles number versus $\mathrm{NO}_{\mathrm{x}}$ concentrations increased when the ambient air temperature was decreasing.

The differences in the aerosol mean concentration and in the intensity of the winter maximum observed at the three studied cities are strongly related to the meteorological features described above (Fig. 1). The enhanced condensation conditions at MILAN with respect to the other sites are favoured by: 1) lower winter temperatures, and 2) the much lower boundary layer depth (which increases the concentrations of the gaseous precursors) due to the frequent occurrences of winter temperature inversions layers. This enhanced condensation may accounts for the: 1) larger summer-to-winter increase in $\mathrm{OM}, \mathrm{DpN}$ and $\mathrm{N}>100$ $(\mathrm{nm})$ at MILAN than the other sites (see these ratios in the upper left corner of Figs. 6c, g, j), 2) much higher winter $(\sim 9.5)$ than summer $(\sim 5.8) \mathrm{OM} / \mathrm{BC}$ ratios at MILAN, whereas these ratios remains relatively constant from summer to winter both at BARCELONA ( 5.2) and LONDON $(\sim 5.6)$. Notice how the most important "summer-to-winter" 


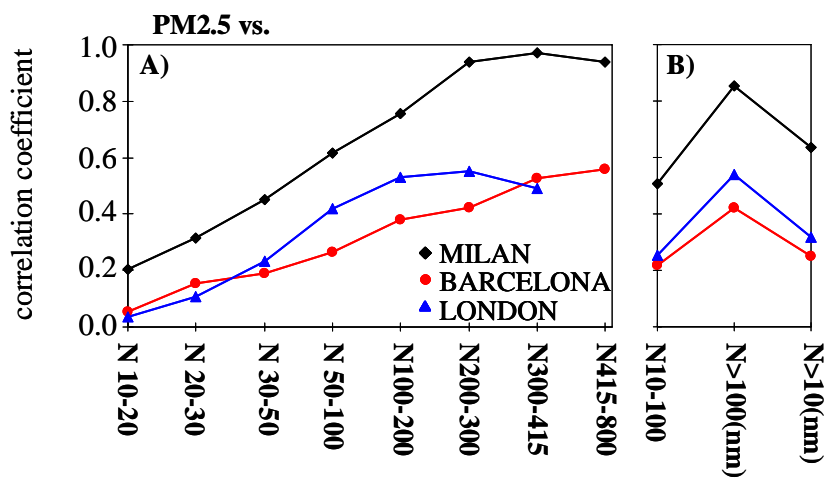

Fig. 9. Correlation coefficient between the aerosol hourly "mass $\mathrm{PM}_{2.5}$ concentrations" and "number concentration (in several size ranges)" during the 1-year study period (each value obtained with more than 8000 hourly data).

and "daylight-to-night" DpN increases are observed in MILAN (Figs. 3c, 6h and 8), where the highest concentrations of semi-volatile components (ammonium-nitrate and unidentified OM species) are recorded. These results show how the content in semi-volatile species in $\mathrm{PM}_{2.5}$ also influences the variability of the particles size distribution.

4.6 Relationship between $\mathrm{PM}_{2.5}$ and number size distribution

In the examples shown in Fig. 7, it can be observed how the total number concentration $\mathrm{N}>10(\mathrm{~nm})$ also tend to increase from the "clean air" to the "urban pollution" events, frequently from $<1 \times 10^{4}$ to $>2 \times 10^{4} \mathrm{~cm}^{-3}$. However, the degree of correlation between $\mathrm{PM}_{2.5}$ and the number concentration changes significantly depending on the particle size. Observe how (Fig. 7): 1) $\mathrm{N}>100$ (nm) and $\mathrm{PM}_{2.5}$ exhibit day-today correlated variations; 2) N10-100 may exhibit concentrations equally high during both high and low $\mathrm{PM}_{2.5}$ concentrations episodes; 3) N10-30 may reach even higher concentrations during low rather than during high $\mathrm{PM}_{2.5}$ conditions. The relationship between the aerosol $\mathrm{PM}_{2.5}$ mass concentrations and the number size distribution has been studied by: A) calculating and analysing the correlation coefficient between $\mathrm{PM}_{2.5}$ and the number concentration in several size ranges (Fig. 9); B) analysing the "scatter plots" of $\mathrm{PM}_{2.5}$ versus the number concentration in several size ranges (Fig. 10), and 3) calculating and analysing the correlation coefficient between the main $\mathrm{PM}_{2.5}$ chemical constituents and the number concentration in several size ranges (Fig. 11). The following discussion is based on these analysis performed over the 1 year database.

As the particle mass increases with the particle size, the correlation between $\mathrm{PM}_{2.5}$ and number concentrations increases with the particle diameter, from " $\mathrm{r}$ " $<0.2$ for 10 $20 \mathrm{~nm}$ to $0.6-1.0$ for $>400 \mathrm{~nm}$ (Fig. 9a). As consequence, $\mathrm{PM}_{2.5}$ correlates much better with $\mathrm{N}>100(\mathrm{~nm})$ (a fraction which only accounts for a $15-20 \%$ of the total number concentration $\mathrm{N}>10(\mathrm{~nm})$ ) than with the dominant ultrafine fraction N10-100 (Fig. 9).

The correlation of most of the $\mathrm{PM}_{2.5}$ components with the number concentration increases with the particle diameter (Figs. 11c-k, this analysis is not available for LONDON). This is more clearly observed for secondary species such as nss- $\mathrm{SO}_{4}^{=}, \mathrm{NO}_{3}^{-}$and $\mathrm{NH}_{4}^{+}$(Fig. 11f, g and $\mathrm{h}$ ), whose gas-toparticle conversion rates onto the surface of pre-exiting particles are favoured under the presence of particles with a large surface (such as those $>100 \mathrm{~nm}$; Fig. 2b) in accordance with the Kelvin effect - equilibrium vapour pressure over a sphere increases when the sphere's diameter decreases. In contrast, $\mathrm{BC}$ and $\mathrm{OM}$ exhibit high " $\mathrm{r}$ " values for both the ultrafine and $>100 \mathrm{~nm}$ size fraction due to the primary vehicle emissions and the subsequent particle growth by coagulation and condensation (Figs. 11d-e). Observe how BC and OM are the only components exhibiting a significant correlation with the ultrafine N10-100 particles (Figs. 11a-b). These size distributions of the correlation coefficients (Figs. 11c-k) resemble those of the chemical $\mathrm{PM}_{2.5}$ components obtained by cascade impactor sampling (Putaud et al., 2004; Cabadas et al., 2004).

Because both the particle's surface and mass increases with the particle's diameter, the $\mathrm{N}>100(\mathrm{~nm})$ number, mass $\mathrm{PM}_{2.5}$ concentration and surface concentrations are positively correlated (Figs. 9, 10c-d). This indicates that: 1) an increase in $\mathrm{N}>100(\mathrm{~nm})$ results in an increase of the aerosol surface available for gas-to-particle transfer of matter by condensation; 2) "urban $\mathrm{PM}_{2.5}$ pollution events" mostly occurs when particles are grown enough to result in high $\mathrm{N}>100$ $(\mathrm{nm})$ values (e.g. by condensation onto the surface of preexisting particles of ammonium-nitrate; Figs. 11f-h). Observe in Fig. 7 how $\mathrm{N}>100(\mathrm{~nm})$ is the only particle size fraction that exhibits high concentrations during $\mathrm{PM}_{2.5}$ episodes.

\section{7 $\quad \mathrm{PM}_{2.5}$ versus ultrafine particles events}

The analysis described above (Figs. 7-11) also allowed study of the relationship between aerosol $\mathrm{PM}_{2.5}$ mass and ultrafine N10-100 particles events.

The relationship of the ultrafine N10-100 fraction (and its subsets) with $\mathrm{PM}_{2.5}$ is more complex than the "simple positive correlation between $\mathrm{PM}_{2.5}$ and $\mathrm{N}>100(\mathrm{~nm})$ ". Observe in Fig. 7 how N10-30, N10-100 and N>10 (nm) may exhibits high concentrations during both high and low $\mathrm{PM}_{2.5}$ events. According to the involvement of the different microphysical processes on the relationship between $\mathrm{PM}_{2.5}$ and ultrafine particles, these events are distinguished as follows:

A) Simultaneous high or low " $\mathrm{PM}_{2.5}$ and N10-100 events" are observed during concatenations of some "clean air" and " $\mathrm{PM}_{2.5}$ pollution" events (e.g. 1-7 and 29-31 March 2004 at MILAN, 1-9 February 2004 at BARCELONA or 1-12 November 2003 at LONDON; Fig. 7), when the previously discussed influence of meteorology results in the increase 

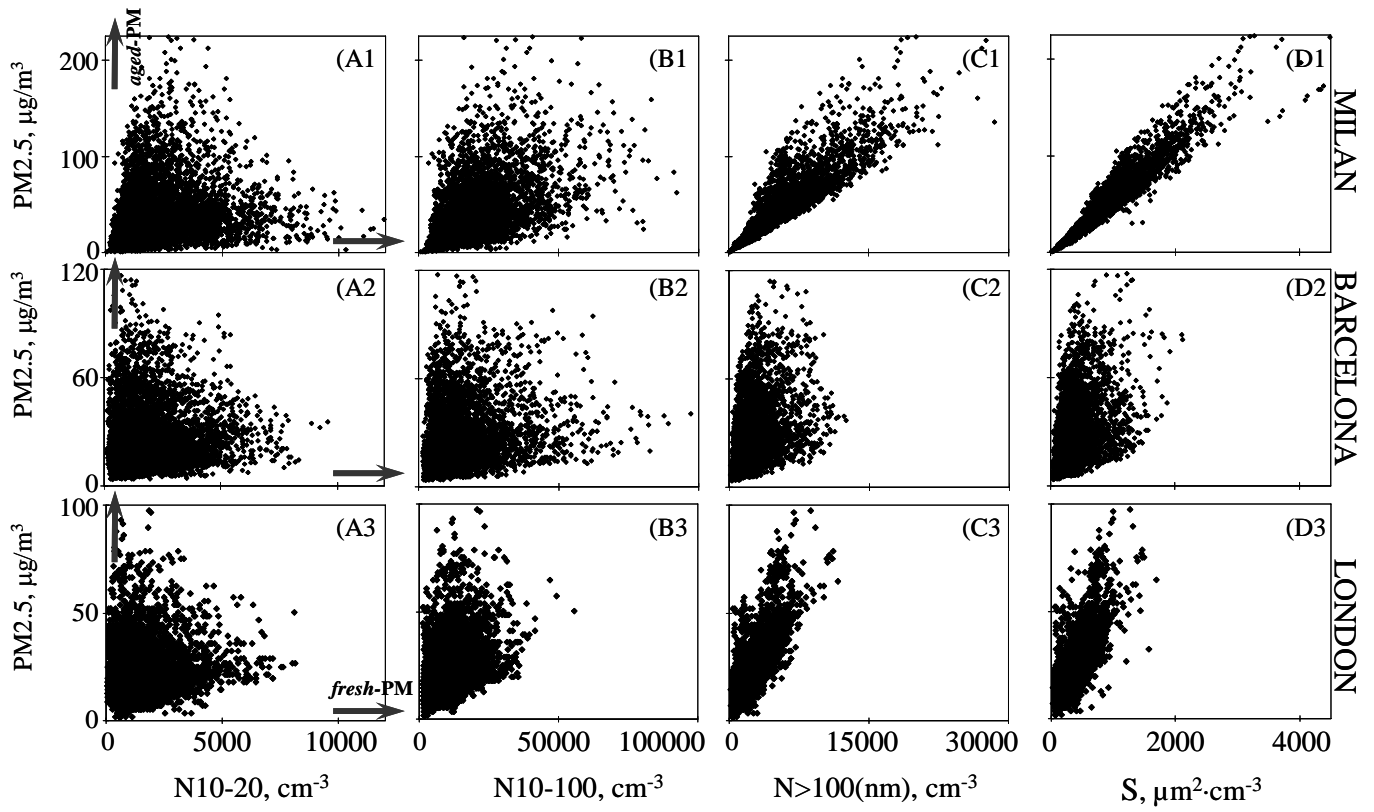

Fig. 10. Hourly mean aerosol $\mathrm{PM}_{2.5}$ mass concentrations versus number concentrations (in several size ranges) during the 1-year study period.
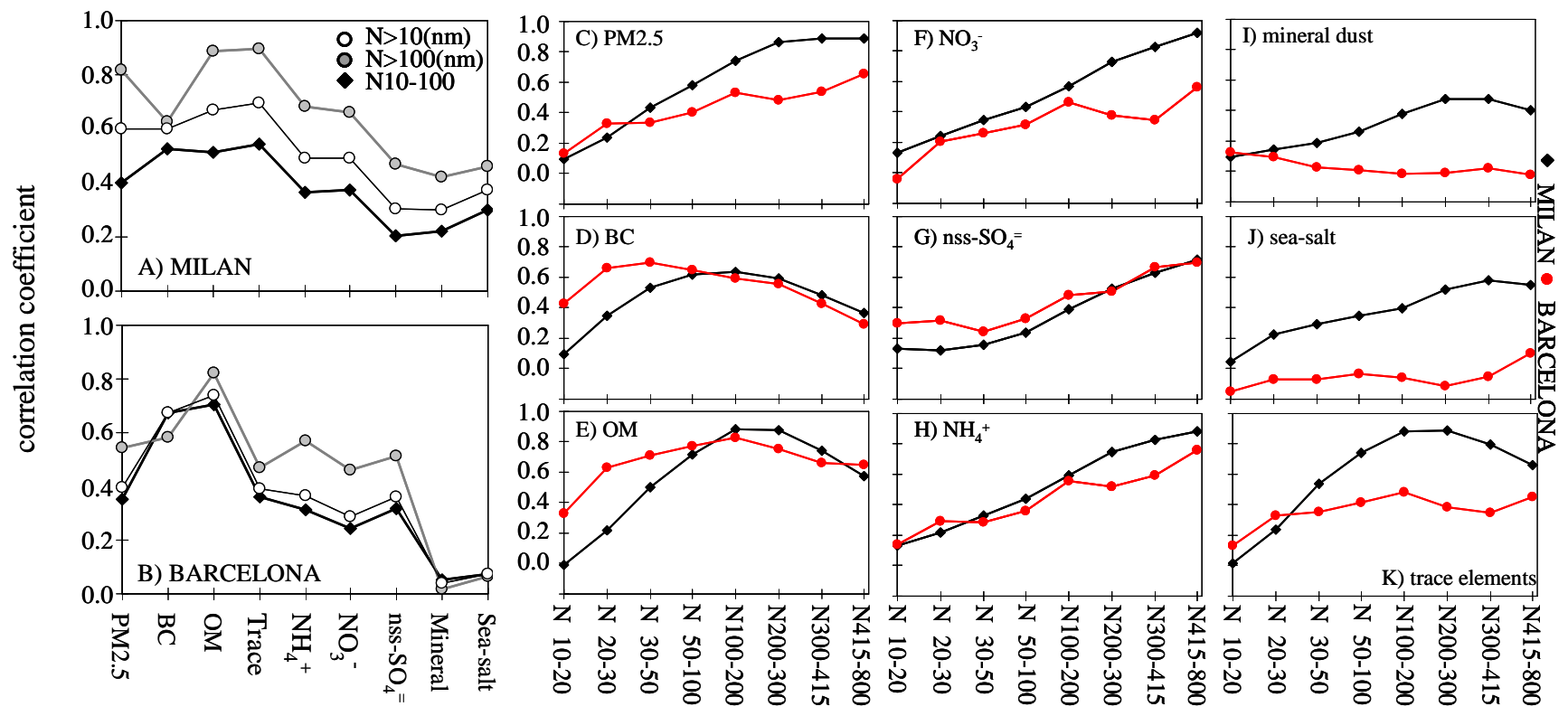

Fig. 11. Correlation coefficient between the daily mean aerosol $\mathrm{PM}_{2.5}$ mass concentrations and number concentrations (in several size ranges) during the 1-year study period.

or decrease of PM concentrations. The data of the central part of the $\mathrm{PM}_{2.5}$ vs. N10-30 and $\mathrm{PM}_{2.5}$ vs. N10-100 scatter plots are associated with this type of events (Figs. 10a-b). During these episodes, the increase in $\mathrm{PM}_{2.5}$ levels occur because particles have grown enough to produce a significant $\mathrm{N}>100(\mathrm{~nm})$ values (observe in Fig. 7 the $\mathrm{DpN}$ and $\mathrm{N}>100$ $(\mathrm{nm})$ increases during the above cited examples).
B) Low $\mathrm{PM}_{2.5}$ and high $\mathrm{N} 10-100$ episodes (also associated with N10-30 events) are frequently recorded (e.g. 2024 of March 2004 at MILAN, 9-13 and 17 of February 2004 at BARCELONA and 21-22 and 24 of November 2003 at LONDON; Fig. 7). These events are caused by the occurrence of "very small fresh particles" (observe in Fig. 7 the low "DpN and N>100 (nm)" and high "N10-30" values 
during the above cited examples) associated with two possible processes: 1) recent primary emissions (e.g. BC and some OM species) and 2) new particles formation by nucleation (e.g. sulphate and some OM species; Jung et al., 2006). The fact that the aerosol surface concentrations are low during these events (Fig. 10d) favours the occurrence of these very small particles, because under low aerosol surface concentrations: (i) the coagulation rates remain low (increasing the residence time of these fresh small particles), and (ii) the condensation rates decreases and consequently the gasto-particle transfer of matter by nucleation is favoured with respect to higher $\mathrm{PM}_{2.5}$ concentration events (note that condensation and nucleation are competing processes, the first being favoured under high aerosol surface concentrations and vice versa; see a discussion on this in Rodríguez et al., 2005). This type of events accounts for the data located in the right lower corner ("labelled as fresh PM") of the $\mathrm{PM}_{2.5}$ vs. N1030 and $\mathrm{PM}_{2.5}$ vs. N10-100 scatter plots (Figs. 10a-b).

C) High $\mathrm{PM}_{2.5}$ and low N10-100 episodes. Examples (Fig. 7): 4 and 13-15 March 2004 at MILAN and 7, 1819 and 21 February 2004 at BARCELONA. The following mechanisms may be involved in these events: 1) an enhancement of coagulation and condensation processes in relatively "aged air" (e.g. during pollution events at night; Figs. 8c), and 2) the presence of high density primary particles (e.g. fly-ashes, metals or mineral local or Saharan dust). These types of events account for the data located in the left upper corner ("labelled as aged PM" according to the first mechanism cited above) of the $\mathrm{PM}_{2.5}$ vs. N10-30 and $\mathrm{PM}_{2.5}$ vs. N10-100 scatter plots (Figs. 10a-b).

The influence of the above cited mechanisms favouring the presence of ultrafine particles under low $\mathrm{PM}_{2.5}$ concentrations is also observed in Fig. 8: the decrease in the aerosol concentrations from "high-to-mid" and "mid-to-low" $\mathrm{PM}_{2.5}$ events exhibits ratios $\sim 0.5$ for $\mathrm{PM}_{2.5}, 0.6$ for $\mathrm{N}>100(\mathrm{~nm})$, 0.8 for $\mathrm{N} 10-100$ and 0.9 for $\mathrm{N} 10-30$ at the 3 sites. Observe how the decrease is much less important for ultrafine particles. This could have implications for air quality improvements strategies: "a decrease in the 'accumulation mode particles' (which accounts for the most important proportion of the aerosol surface) may raise the ultrafine particles number concentration in urban air." The relationships leading to these conclusions have also been observed in urban and rural areas (Wichmann et al., 2000; Laakso et al., 2003; Rodríguez et al., 2005).

\section{Summary and conclusions}

In this article, data on urban fine aerosol particles physicochemical characterization in MILAN, BARCELONA and LONDON were collected and studied. The analysis of the aerosol number size distribution, chemical composition and mass $\mathrm{PM}_{2.5}$ concentrations data, provides a comprehensive picture on the involvement of the different microphysical processes on the aerosol dynamics (i.e. nucleation, coagulation, condensation, evaporation, deposition prompted by Brownian diffusion, etc...) in the regular evolution of the urban aerosol in a daily, weekly and seasonal basis as well as in the aerosol evolution from clean-air to pollution episodes.

Mean concentrations of $\mathrm{PM}_{2.5}$ and $\mathrm{N}>10(\mathrm{~nm})$ at the three sites are within the range of typical values across Western Europe, $\mathrm{PM}_{2.5}$ : $20-45 \mu \mathrm{g} / \mathrm{m}^{3}$ and $\mathrm{N}>10(\mathrm{~nm})$ : 10 $25 \times 10^{3} \mathrm{~cm}^{-3}$, being the highest concentrations recorded in MILAN and the lowest in LONDON. Ultrafine particles N10-100 accounts $80-85 \%$ of the total number concentration of fine aerosol, being the number size distribution mode $(\mathrm{DpN})$ about $\sim 37 \mathrm{~nm}$. The results of this study evidence the much higher levels of: 1) "mineral dust" in the Mediterranean cities $\left(4.6 \mu \mathrm{g} / \mathrm{m}^{3}\right.$ in BARCELONA, $1.7 \mu \mathrm{g} / \mathrm{m}^{3}$ in MILAN and $0.6 \mu \mathrm{g} / \mathrm{m}^{3}$ in LONDON) and 2) organic matter and ammonium-nitrate in the Po Valley (MILAN $7.0 \mu \mathrm{gNO}_{3}^{-} / \mathrm{m}^{3}, 5.5 \mu \mathrm{gOM} / \mathrm{m}^{3}$ and $2.5 \mu \mathrm{gNH}_{4}^{+} / \mathrm{m}^{3}$ higher than in BARCELONA and LONDON). The links between "aerosol chemical composition and mass concentrations" with the "number size distribution" have been studied in terms of the involvement of the microphysical processes.

The $\mathrm{PM}_{2.5}$ mass concentrations exhibit a high correlation with the number concentration of particles $>100 \mathrm{~nm}(\mathrm{~N}>100$ $(\mathrm{nm})$ which only accounts for $<20 \%$ of the total number concentration of particles $>10 \mathrm{~nm}$ ) but do not exhibit a significant correlation with the ultrafine particles number concentration (N10-100 which accounts for $>80 \%$ of the total number concentration of particles $>10 \mathrm{~nm}$ ). Moreover: 1) ammonium-nitrate and ammonium-sulphate are significantly correlated with $\mathrm{N}>100(\mathrm{~nm})$, being this attributed to particle growth processes and to gas-to-particle conversion mechanisms involving "condensation onto" and/or "reaction with" the surface of pre-existing particles, 2) organic matter (OM) and black-carbon (BC) are the only aerosol compounds significantly correlated with the number concentration of ultrafine $\mathrm{N}<100(\mathrm{~nm})$ particles, and are also correlated with $\mathrm{N}>100$ (nm), being this attributed to vehicle exhaust emissions and subsequent particle growth due to coagulation and condensation processes.

The results of this study show that in urban environments: 1) $\mathrm{PM}_{2.5}$ is mainly weighted by the accumulation mode particles $(0.1-1 \mu \mathrm{m})$ linked to the "urban aerosol background" and consequently is highly affected by the microphysical processes contributing to $\mathrm{N}>100$ (nm), such as "condensation or reaction of gases onto the particles surface" and particles growth processes (e.g. by coagulation), and 2) the total number concentration $\mathrm{N}>10(\mathrm{~nm})$ is mainly weighed by the ultrafine particles, which are highly influenced by the fresh vehicle exhausts emissions, and exhibits a relatively short residence time because the effects of coagulation and deposition prompted by Brownian diffusion. Because of this, the variations on $\mathrm{PM}_{2.5}$ and $\mathrm{N}>100(\mathrm{~nm})$ concentrations tend to be smoother than those in the total $\mathrm{N}>10(\mathrm{~nm})$ and ultrafine N10-100 particles number concentration. The above 
described relationships that lead to these conclusions are consistently observed all across the analysis of the daily, weekly and seasonal evolution, as well as in the day-to-day basis.

Other relevant observations which highlight the influence of the aerosol microphysics on the particles $\mathrm{PM}_{2.5}$ and $\mathrm{N}$ concentrations, and size distributions are:

- Daily evolution. Because the diurnal "primary vehicle exhaust emissions, nucleation and evaporation processes" and the nocturnal "particle growth by condensation and coagulation", aerosol tend to be smaller during daylight (size distribution modes within the range $35-50 \mathrm{~nm}$ ) than at night (size distribution modes 50$70 \mathrm{~nm}$ ). The vehicle exhaust emissions results in a much higher increase in the ultrafine than in the $>100 \mathrm{~nm}$ particles: "nocturnal-background" to "morning rush hours" increases of 1.5-2.5 for ultrafine N10-100 particles and $<1.5$ for $\mathrm{N}>10(\mathrm{~nm})$ and $\mathrm{PM}_{2.5}$ are typically registered.

- $\mathrm{PM}_{2.5}$ pollution events and seasonal evolution. Time series of the daily mean values of the size distribution mode $(\mathrm{DpN}), \mathrm{PM}_{2.5}$ and $\mathrm{N}>100(\mathrm{~nm})$ tend to exhibit day-to-day correlated variations during the concatenation of "urban pollution events" and "classical clean air episodes (in terms of $\mathrm{PM}_{2.5}$ )". This tendency to increase the particles DpN diameter when increasing $\mathrm{PM}_{2.5}$ concentrations is attributed to condensation of semi-volatile species, being ammonium-nitrate (and organic matter in MILAN) the component exhibiting the highest increase from "mid"-to-"high" $\mathrm{PM}_{2.5}$ episodes (when the highest $\mathrm{DpN}$ increase are observed). These results indicates that $\mathrm{PM}_{2.5}$ events tend to occur when condensation processes have made particles grown enough to produce significant concentrations of $\mathrm{N}>100(\mathrm{~nm})$.

- Ultrafine N10-100 versus $\mathrm{PM}_{2.5}$. Because the very low contribution of the ultrafine N10-100 particles to the $\mathrm{PM}_{2.5}$ particles mass concentrations, N10-100 do not shows a systematic positive or negative correlation with $\mathrm{PM}_{2.5} . \quad \mathrm{N}>100(\mathrm{~nm})$ is the only particle size-fraction which exhibits high concentration only during $\mathrm{PM}_{2.5}$ episodes. Events of low $\mathrm{PM}_{2.5}$ and high N10-100 concentrations occur frequently. Although it is known that these events are caused by "fresh primary vehicles exhaust emissions" and/or "new particle formation by nucleation", it is still unknown what the contribution of each of such processes is. This would be a fruitful subject for future research.

Finally, these results have also important implications, from a technical point of view, for urban air quality monitoring. These results show how the number concentration $\mathrm{N}$ and $\mathrm{PM}_{2.5}$ exhibits some properties which are complementary for monitoring the urban air quality: " $\mathrm{N}$ is highly sensitive to the 'fresh vehicles exhaust emissions' of ultrafine particles, whereas $\mathrm{PM}_{2.5}$ is highly influenced by the 'aged aerosol linked to the urban and regional background' mostly occurring in the accumulation mode $(0.1-1 \mu \mathrm{m})$ due to the emissions of the vehicles and other sources". Thus, because the number $\mathrm{N}$ and mass $\mathrm{PM}_{2.5}$ concentrations are sensitive to different forms of aerosol pollution, their urban concentrations should be monitored. However, if limit values for the ultrafine and/or total number concentration are to be established in the context of the European Union, they should be decided on the basis of epidemiological studies. Although the results of some researches suggests that exposure to ultrafine particles impair human health, the World Health Organization has concluded that more research is still needed to establish the possible links between ultrafine PM exposures and human health impairment (Wichmann et al., 2000; WHO, 2003, and references therein).

Acknowledgements. The Ministry of Education, Culture and Science of Spain provided the: 1) grant to S. Rodríguez for studies at the JRC (Italy) and BGS (UK), and 2) project CGL200405984_C07-02/CLI that contributed to this study. The OC-BC analysis were performed thank to the support of J. J. Cao (Chinese Academy of Sciences) and S. C. Lee. (Hong Kong Polytechnic University). The NOAA-CDC, NOAA-READY, NASA-web-mapviewer products and SKIRON and DREAM Saharan dust transport forecasts contributed to this study. We thank to DIGITEL Company for their "fast response" in supporting our sampling.

Edited by: N. Mihalopoulos

\section{References}

Alastuey, A., Querol, X., Rodríguez, S., Plana, F., Lopez-Soler, A., Ruiz, C., and Mantilla, E.: Monitoring of atmospheric particulate matter around sources of secondary inorganic aerosol, Atmos. Environ., 38, 4979-4992, 2004.

Cabada, J. C., Rees, S., Takahama, S., Khlystov, S. A., Pandis, S. N., Davidson, C. I., and Robinson, A. L.: Mass size distributions and size resolved chemical composition of fine particulate matter at the Pittsburgh supersite, Atmos. Environ., 38, 3127-3141, 2004.

Casati, R., Scheer, V., Vogt, R., and Benter, T.: Measurement of nucleation and soot mode particle emission from a diesel passenger car in real world and laboratory in situ dilution, Atmos. Environ., 41, 2125-2135, 2007.

Cao, J. J. Lee, S. C., Ho, K. F., Zou, S. C., Fung, K., Li, Y., Watson, J. G., and Chow, J. C.: Spatial and seasonal variations of atmospheric organic carbon and elemental carbon in Pearl River Delta Region, China, Atmos. Environ., 38, 4447-4456, 2004.

Gidhagen, L., Johansson, C., Langner, J., and Foltescu, V. L.: Urban scale modelling of particle number concentration in Stockholm, Atmos. Environ., 1711-1725, 2005.

Götschi, T., Hazenkamp-von Arx, M. E., Heinrichc, J., Bono, R., Burney, P., Forsberg, B., Jarvis, D., Maldonado, J., Norbäch, D., Stern, W. B., Sunyer, J., Torén, K., Verlato, G., Simona, V., and Künzl, N.: Elemental composition and reflectance of ambient fine particles at 21 European locations, Atmos. Environ., 39, 5947-5958, 2005. 
Harris, J. S. and Maricq, M. M.: Signature size distributions for diesel and gasoline engine exhaust particulate matter, J. Aerosol Sci., 32, 749-764, 2001.

Hussein, T., Puustinen, A., Aalto, P. P., Mäkela, J. M., Hämeri, K., and Kulmala, M.: Urban aerosol number size distributions, Atmos. Chem. Phys., 4, 391-411, 2004, http://www.atmos-chem-phys.net/4/391/2004/.

IPCC, 2001: Climate Change 2001: The Scientific Basis, Cambridge University Press, 2001.

Janson, R., Rosman, K., Karlsson, A., and Hansson, H. C.: Biogenic emissions and gaseous precursors to forest aerosols, Tellus, Series B, Chemical and physical meteorology, 53, 423-440, 2001.

Jung, J. G., Adams, P. J., and Pandis, S. N.: Simulating the size distribution and chemical composition of ultrafine particles during nucleation events, Atmos. Environ., 40, 2248-2259, 2006.

Ketzel, M., Wåhlin, P., Kristensson, A., Swietlicki, E., Berkowicz, R., Nielsen, O. J., and Palmgren, F.: Particle size distribution and particle mass measurements at urban, near-city and rural level in the Copenhagen area and Southern Sweden, Atmos. Chem. Phys., 4, 281-292, 2004, http://www.atmos-chem-phys.net/4/281/2004/.

Kittelson, D. B.: Engines and nanoparticles: a review, J. Aerosol Sci., 29, 575-588, 1998.

Kulmala, M., Vehkamäki, H., Petäjä, T., Dal Maso, M., Lauri, A., Kerminen, V. M., Birmili, W., and McMurry, P. H.: Formation and growth rates of ultrafine atmospheric particles: a review of observations, J. Aerosol Sci., 35, 143-176, 2004.

Laakso, L., Hussein, T., Aarnio, P., Komppula, M., Hiltunen, V., Viisanen, Y., and Kulmala, M.: Diurnal and annual characteristics of particle mass and number concentrations in urban, rural and Arctic environments in Finland, Atmos. Environ., 37, 26292641, 2003.

Millán, M. M., Sanz, M. J., Salvador, R., and Mantilla, E.: Atmospheric dynamics and ozone cycles related to nitrogen deposition in the western Mediterranean, Environ. Pollut., 118, 167-186, 2002.

Putaud, J. P., Raes, F., Van Dingenen, R., et al.: A European Aerosol Phenomenology. 2: physical characteristics of particulate matter at kerbside, urban, rural and background sites in Europe, Atmos. Environ., 38, 2579-2595, 2004.

Querol, X., Alastuey, A., Rodriguez, S., Plana, F., Ruiz, C. R., Cots, N., Massague, G., and Puig, O.: $\mathrm{PM}_{10}$ and $\mathrm{PM}_{2.5}$ source apportionment in the Barcelona Metropolitan area, Catalonia, Spain, Atmos. Environ., 35, 6407-6419, 2001.

Querol, X., Alastuey, A., Ruiz, C. R., Artíñano, B., Hansson, H. C., Harrison, R. M., Buringh, E., ten Brink, H. M., Lutz, M., Bruckmann, P., Straehl, P., and Schneide, J.: Speciation and origin of $\mathrm{PM}_{10}$ and $\mathrm{PM}_{2.5}$ in selected European cities, Atmos. Environ., 38, 6547-6555, 2004.
Rodríguez, S., Van Dingenen, R., Putaud, J. P., Martins-Dos Santos, S., and Roselli, D.: Nucleation and growth of new particles in the rural atmosphere of Northern Italy - Relationship to Air Quality Monitoring, Atmos. Environ., 39, 6734-6746, 2005.

Rodríguez, S., Querol, X., Alastuey, A., and de la Rosa, J.: Atmospheric particulate matter and air quality in the Mediterranean: a review, Environ. Chem. Lett., 5, 1-7, doi:10.1007/s10311-0060071-0, 2006.

Ruuskanen, J., Tuch, Th., Ten Brink, H., Peters, A., Khlystov, A., Mirme, A., Kos, G. P. A., Brunekreef, B., Wichmann, H. E., Buzorius, G., Vallius, M., Kreyling, W. G., and Pekkanen, J.: Concentrations of ultrafine, fine and $\mathrm{PM}_{2.5}$ particles in three European cities, Atmos. Environ., 35, 3729-3738, 2001.

Sun, Q., Wang, A., Jin, X., Natanzon, A., Duquaine, D., Brook, R. D., Aguinaldo, J. G. S., Fayad, Z. A., Fuster, V., Lippman, M., Chen, L. C., and Rajagopalan, S.: Long-term Air Pollution Exposure and Acceleration of Atherosclerosis and Vascular Inflammation in an Animal Model, J. Amer. Medical Assoc., 294(23), 3003-3010, 2005.

Van Dingenen, R., Raes, F., Putaud, J. P., et al.: A European Aerosol Phenomenology. 1: physical characteristics of particulate matter at kerbside, urban, rural and background sites in Europe, Atmos. Environ., 38, 2561-2577, 2004.

Weber, R. J., Orsini, D., Daun, Y., Lee, Y. N., Klotz, P. J., and Brechtel, F. A particle-into- liquid collector for rapid measurement of aerosol bulk chemical composition, Aerosol Sci. Technol., 35, 718-727, 2001.

Wehner, B., Birmili, W., Gnauk, T., and Widensohler, A.: Particle number size distributions in a street canyon and their transformation into the urban-air background: measurements and a simple model study, Atmos. Environ., 36, 2215-2223, 2002.

Wehner, B. and Widensohler, A.: Long term measurements of submicron urban aerosols: statistical analysis for correlations with meteorological conditions and trace gases, Atmos. Chem. Phys., 3, 867-879, 2003, http://www.atmos-chem-phys.net/3/867/2003/.

WHO, World Health Organization: Health Aspects of Air Pollution with Particulate Matter, Ozone and Nitrogen Dioxide, Report on a WHO Working Group, Bonn, Germany, 13-15 January 2003.

Wichmann, H. E., Spix, C., Tuch, T., Wölke, G., Peters, A., Heinrich, J., Kreyling, G., and Heyder, J.: Daily mortality and fine and ultrafine particles in Erfurt, Germany. Part-I: Role of particle number and particle mass, Health Effects Institute, Research Report, number 98, November 2000. 